Louisiana State University

LSU Digital Commons

$4-1-2013$

\title{
Improved tolerance to salt and water stress in Drosophila melanogaster cells conferred by late embryogenesis abundant protein
}

\author{
Matthew R. Marunde \\ Eastern Illinois University \\ Dilini A. Samarajeewa \\ Eastern Illinois University \\ John Anderson \\ Eastern Illinois University \\ Shumin Li \\ Eastern Illinois University \\ Steven C. Hand \\ Eastern Illinois University
}

See next page for additional authors

Follow this and additional works at: https://digitalcommons.Isu.edu/biosci_pubs

\section{Recommended Citation}

Marunde, M., Samarajeewa, D., Anderson, J., Li, S., Hand, S., \& Menze, M. (2013). Improved tolerance to salt and water stress in Drosophila melanogaster cells conferred by late embryogenesis abundant protein. Journal of Insect Physiology, 59 (4), 377-386. https://doi.org/10.1016/j.jinsphys.2013.01.004 


\section{Authors}

Matthew R. Marunde, Dilini A. Samarajeewa, John Anderson, Shumin Li, Steven C. Hand, and Michael A. Menze 
Eastern Illinois University

The Keep

Faculty Research \& Creative Activity

Biological Sciences

January 2013

Improved Tolerance to Salt and Water Stress in Drosophila melanogaster Cells Conferred by Late Embryogenesis Abundant Protein

Matthew R. Marunde

Eastern Illinois University

Dilini A. Samarajeewa

Eastern Illinois University

John Anderson

Eastern Illinois University

Shumin Li

Louisiana State University and Agricultural \& Mechanical College

Steven C. Hand

Louisiana State University

See next page for additional authors

Follow this and additional works at: http://thekeep.eiu.edu/bio_fac

Part of the Biology Commons, Cellular and Molecular Physiology Commons, and the Systems and Integrative Physiology Commons

\section{Recommended Citation}

Marunde, Matthew R.; Samarajeewa, Dilini A.; Anderson, John; Li, Shumin; Hand, Steven C.; and Menze, Michael A., "Improved Tolerance to Salt and Water Stress in Drosophila melanogaster Cells Conferred by Late Embryogenesis Abundant Protein" (2013). Faculty Research \& Creative Activity. 119.

http://thekeep.eiu.edu/bio_fac/119

This Article is brought to you for free and open access by the Biological Sciences at The Keep. It has been accepted for inclusion in Faculty Research \& Creative Activity by an authorized administrator of The Keep. For more information, please contact tabruns@eiu.edu. 
Authors

Matthew R. Marunde, Dilini A. Samarajeewa, John Anderson, Shumin Li, Steven C. Hand, and Michael A. Menze 


\section{Improved Tolerance to Salt and Water Stress in Drosophila melanogaster Cells Conferred by Late Embryogenesis Abundant Protein}

Matthew R. Marunde, Dilini A. Samarajeewa, John Anderson, Shumin Li ${ }^{\#}$, Steven C. Hand ${ }^{\#}$, and Michael A. Menze*

Department of Biological Science, Eastern Illinois University, Charleston, Il. 61920 USA

${ }^{\#}$ Department of Biological Sciences, Louisiana State University, Baton Rouge, LA 70803 USA

Matthew R. Marunde: mrmarunde@eiu.edu

Dilini A. Samarajeewa: dsdiyagamaarac@eiu.edu

John Anderson: jand142@tigers.1su.edu

Shumin Li: shuminli1@gmail.com

Steven C. Hand: schand@1su.edu

Michael A. Menze: mmenze@eiu.edu

*Corresponding author: Tel.: 217-581-6386; Fax: 217-581-7141; Email: mmenze@eiu.edu 


\section{Graphical Abstract}

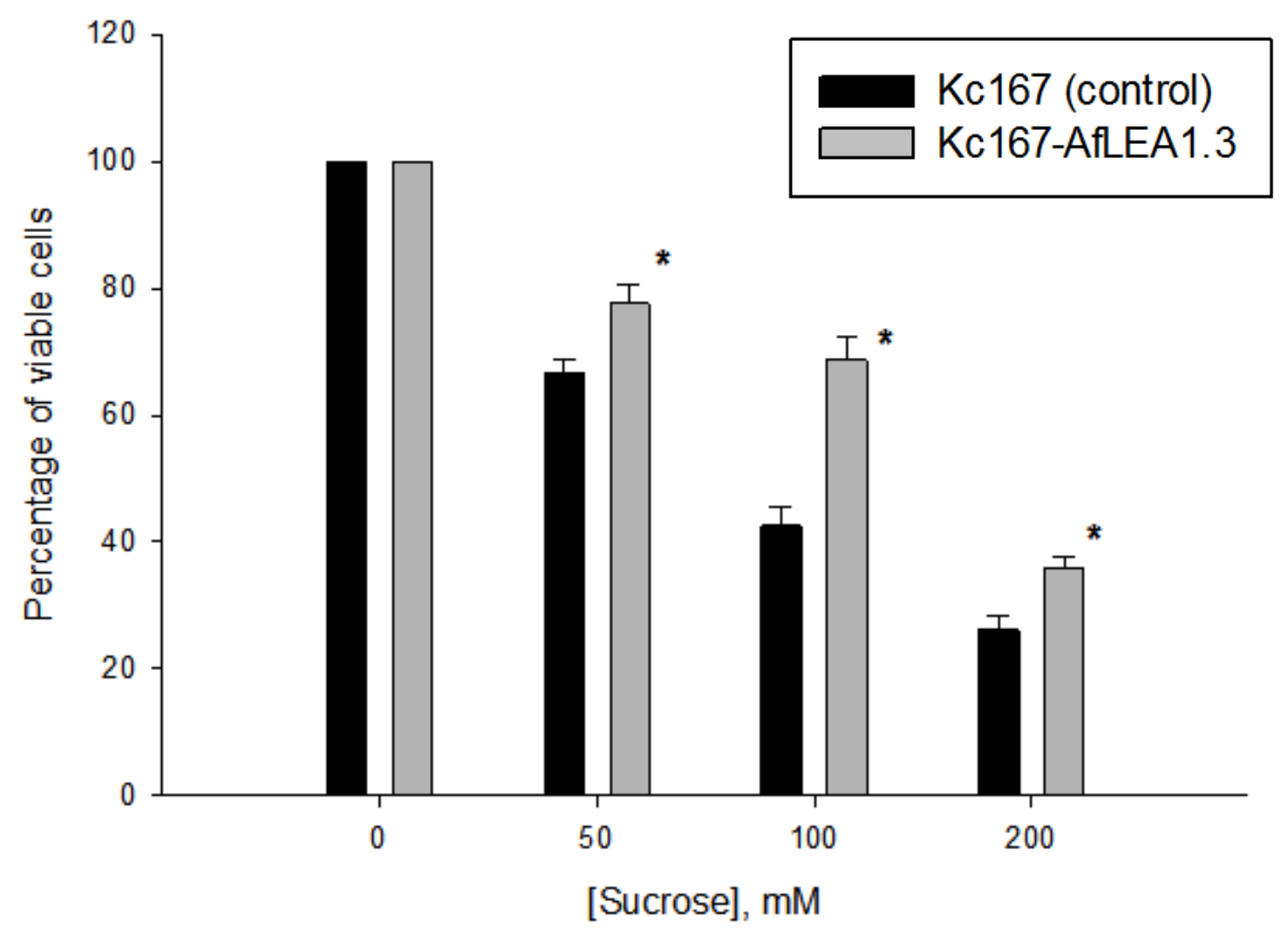

\section{Highlights:}

$>\quad$ The Late Embryogenesis Abundant protein AfLEA1.3 from Artemia franciscana accumulates in the mitochondrion of Drosophila Kc167 cells.

$>\quad$ AfLEA1.3 improves mitochondrial functions in presence of high sodium chloride concentrations.

$>\quad$ AfLEA1.3 reduces mitochondrial damage during freeze-thawing.

$>\quad$ AfLEA1.3 increases cellular tolerance to osmotic stress.

$>\quad$ AfLEA1.3 increases cellular tolerance to convective drying.

Keywords: Mitochondria, water stress, bioenergetics, cellular respirometry, cryopreservation 


\section{LIST OF ABBREVIATIONS}

$\begin{array}{ll}\text { DW } & \text { dry weight } \\ \text { EC }_{50} & \text { effector concentration that yields half-maximal response } \\ \text { LEA } & \text { late embryogenesis abundant } \\ \text { OMM } & \text { outer mitochondrial membrane } \\ \text { ROX } & \text { residual oxygen consumption }\end{array}$




\begin{abstract}
Mechanisms that govern anhydrobiosis involve the accumulation of highly hydrophilic macromolecules, such as late embryogenesis abundant (LEA) proteins. Group 1 LEA proteins comprised of 181 (AfLEA1.1) and 197 (AfLEA1.3) amino acids were cloned from embryos of Artemia franciscana and expressed in Drosophila melanogaster cells (Kc167). Confocal microscopy revealed a construct composed of green fluorescence protein (GFP) and AfLEA1.3 accumulates in the mitochondria (AfLEA1.3-GFP), while AfLEA1.1-GFP was found in the cytoplasm. In the presence of mixed substrates, oxygen consumption was statistically identical for permeabilized Kc167 control and Kc167-AfLEA1.3 cells. Acute titrations of permeabilized cells with $\mathrm{NaCl}$ up to $500 \mathrm{mM}$ led to successive drops in oxygen flux, which were significantly ameliorated by $18 \%$ in Kc167-AfLEA1.3 cells compared to Kc167 controls. Mitochondria were isolated from both cell types and resuspended in a sucrose-based buffer solution. The purified mitochondria from Kc167 control cells showed significantly larger reductions in respiratory capacities after one freeze-thaw cycle $\left(-80^{\circ} \mathrm{C}\right)$ compared to mitochondria isolated from Kc167AfLEA1.3 cells. When cultured in the presence of a non-permeant osmolyte $(50-200 \mathrm{mM}$ sucrose) cells expressing AfLEA1.3 showed significantly improved viability (10 - 15\%) during this hyperosmotic challenge as compared to Kc167 controls. Furthermore, Kc167-AfLEA1.3 cells survived desiccation by convective air drying in presence of $200 \mathrm{mM}$ extracellular trehalose to lower final moisture contents than did control $\mathrm{Kc} 167$ cells $\left(0.36 \mathrm{~g} \mathrm{H}_{2} \mathrm{O} / \mathrm{g} \mathrm{DW}\right.$ vs.1.02 g H $\mathrm{H}_{2} \mathrm{O} / \mathrm{g}$ DW). Thus, AfLEA1.3 exerts a protective influence on mitochondrial function and increases viability of Kc167 cells during water stress.
\end{abstract}




\section{INTRODUCTION}

Deficit of cellular water is a common condition in xeric climates that threatens the survival of plants and animals (Yancey et al., 1982). Although severe loss of water is often detrimental to life, some invertebrate animals from a few phyla have developed mechanisms to cope with extreme desiccation by entering a state known as anhydrobiosis (Clegg, 2001; Crowe and Clegg, 1973; Crowe et al., 1992; Keilin, 1959; Watanabe et al., 2005). Anhydrobiotic organisms possess the ability to survive desiccation in nature to water contents around $0.02-0.05 \mathrm{~g} \mathrm{H}_{2} \mathrm{O} \mathrm{g}^{-1} \mathrm{dry}$ mass and enter into a state that approaches suspended animation (Clegg, 1973; Crowe and Madin, 1974, 1975; Hinton, 1968). Desiccation tolerance has also been observed in some flowering plants, algae, fungi, bacteria, and most seeds of higher plants are desiccation tolerant (Billi and Potts, 2002; Crowe et al., 1992; Hoekstra et al., 2001; Potts, 1999). In the study presented here, we demonstrate that a mitochondrial targeted group 1 Late Embryogenesis Abundant (LEA) protein from the brine shrimp Artemia franciscana confers cellular protection and increases mitochondrial performance under water-stress conditions in transgenic cells (Kc167) from Drosophila melanogaster.

A recurring strategy in animals to tolerate extreme water loss is the expression of LEA proteins with or without the concurrent accumulation of large amounts of the non-reducing disaccharide trehalose (Goyal et al., 2005; Hand et al., 2011; Oliver et al., 2001; Tunnacliffe and Lapinski, 2003; Watanabe et al., 2005). LEA proteins were first described about 30 years ago in desiccation tolerant cotton seeds at maturation (Dure and Galau, 1981; Galau, 1986) and were thought to be unique to plants. LEA proteins were found to reduce the damage to seeds and seedlings by harsh environmental conditions such as drought, freezing, and osmotic stress (Bray, 1993; Espelund et al., 1992; Hundertmark and Hincha, 2008; Pammenter and Berjak, 1999; Shih et al., 2008). Our knowledge about the occurrence of LEA and LEA-like proteins in animals is increasing rapidly, and since 2000, when the first LEA-like protein was reported in an invertebrate species (Solomon et al., 2000), more than 30 other LEA and LEA-like protein sequences have been deposited into the database of the National Center for Biotechnology Information (NCBI) from animals belonging to several phyla including Arthropoda, Rotifera, and Nematoda (Hand et al., 2011).

LEA proteins are highly hydrophilic and intrinsically disordered proteins thought to stabilize other proteins and membranes during desiccation (Shih et al., 2008). Based on sequence 
similarity and amino acid representation, LEA proteins have been assigned to various families and groups, but the mechanisms by which cellular protection is conferred under water stress are still poorly understood (Battaglia et al., 2008; Cuming, 1999; Tunnacliffe and Wise, 2007; Wise and Tunnacliffe, 2004). Interaction with phospholipids was reported for COR15am, a group 3 LEA protein, which was shown to interact with membranes during phase transition to the frozen state in Arabidopsis thaliana (Steponkus et al., 1998), and reports suggest that gaining secondary structure during desiccation may contribute to the ability of LEA proteins to stabilize proteins, membranes, and sugar glasses during drying (Furuki et al., 2011; Li and He, 2009; Wolkers et al., 2001).

The brine shrimp A. franciscana has served as an important model for animal desiccation tolerance, and multiple LEA proteins that belong to group 1 (PF00477), 3 (PF02987), and 4 (PF04927) are found in developmental stages that survive severe desiccation (Hand et al., 2007; Sharon et al., 2009; Wu et al., 2011). Common features of group 1 and 3 LEA proteins are the overrepresented occurrence of hydrophilic amino acids (i.e., glycine content above 6\%), and the presence of identical repeating motifs, while group 4 proteins are conserved in their 70-80 amino acid long N-terminal portion (Battaglia et al., 2008; Wise, 2003). Two features that distinguish group 1 from group 3 are a higher average molecular weight $(25.5 \mathrm{kDa}$ versus $11.5 \mathrm{kDa}$, respectively) and a more acidic $\mathrm{pKa}$ in group 1 proteins as compared to group 3. Additionally, the repeating motifs of group 1 proteins consist of 20 amino acids, while group 3 proteins are characterized by 11-mer motifs (Battaglia et al., 2008). Mitochondrial targeted LEA proteins may help to maintain the integrity and functionality of the organelle when water is scarce through interactions with proteins and membranes but the mechanisms by which protection is conferred are still unclear (Grelet et al., 2005; Menze et al., 2009; Stupnikova et al., 2006; Tolleter et al., 2010; Tolleter et al., 2007).

We demonstrate herein that a 17 amino-acid stretch within the n-terminal region of a group 1 LEA protein from Artemia franciscana is crucial for import into the mitochondrion. The expression of the mitochondrial localized protein in Kc167 cells from Drosophila melanogaster increases cellular viability after desiccation and hyperosmotic stress. Further, for permeabilized Kc167 cells expressing AfLEA1.3, the inhibition of oxidative phosphorylation by $\mathrm{NaCl}$ was significantly reduced compared to permeabilized control cells. Isolated mitochondria from Kc167-LEA1.3 cells maintained significantly higher respiratory capacities after one freeze-thaw 
cycle than mitochondria from Kc167 control cells. The improved response of Kc167-AfLEA1.3 cells and mitochondria to moderate salt and severe water stress suggests that LEA proteins can promote beneficial effects even at high water activities when their conformation is still mostly intrinsically unstructured.

\section{MATERIALS AND METHODS}

\subsection{Chemicals}

All chemicals for respiration measurements were purchased from Sigma-Aldrich (St. Louis, MO) or obtained from Fisher Scientific (Pittsburgh, PA). Water for solution preparation was purified with a Milli-Q Reagent Water System (Millipore, Billerica, MA) to an electrical resistance of 18 $\mathrm{m} \Omega$.

\subsection{Isolation of RNA, preparation of cDNA, and subcloning}

Diapause embryos were incubated for 4 days as reported previously (Reynolds and Hand, 2004) to allow individuals not in diapause to hatch; larvae and empty shells were removed. RNA extractions were performed with an RNeasy Midi kit (Qiagen, Valencia, CA) as per the manufacturer's instructions for animal tissues. The concentration of RNA in each sample was determined spectrophotometrically at $\lambda=260 \mathrm{~nm}$ (Epoch, BioTek, Winooski, VT). The ProtoScript first strand cDNA synthesis kit (New England Biolabs, Ipswich, MA), which utilizes $\mathrm{M}-\mathrm{MuLV}$ reverse transcriptase and oligo-dT (dT23VN) primers, was employed to reverse transcribe total RNA per instructions of the manufacturer. The resulting cDNA was amplified with primers based on a previously published nucleotide sequence (Sharon et al., 2009) encoding a mitochondrial targeted group 1 LEA protein from A. franciscana (ABR67402). Primer sequences used were 5'-CACCATGGAACTGTCGTCGAGTAAG-3' and 5'TTTCTGTCTTGCGAGACCTCC-3'. The PCR product was cloned into the pENTR/D-TOPO cloning vector (Invitrogen, Grand Island, NY) following the instructions of the manufacturer. Several clones were isolated and sequenced. Sequencing utilized BigDye terminator chemistry and an ABI PRISM 3100 Genetic Analyzer (Applied Biosystems, Foster City, CA, USA). Primer walking was used to insure full length sequence was obtained. Sequences were assembled using Sequencher software (Gene Codes Co., Ann Arbor, MI). Two unique clones were obtained that 
encoded for proteins of 180 (AfLEA1.1) and 197 amino acids (AfLEA1.3) (Fig. 1). Both sequences were subcloned into the pIB/V-5-HIS-DEST and pAWG destination vectors using clonase technology (Invitrogen, Grand Island, NY).

\subsection{Cell culture, transfections, and visualization}

The cell line Kc167 from Drosophila melanogaster was obtained from the Drosophila Genomics Resource Center (Bloomington, IN) and grown in $75 \mathrm{~cm}^{2}$ cell culture flasks (Corning Incorporated, Corning, NY). Cells were cultured in Shields and Sang M3 insect medium (SigmaAldrich, St. Louis, MO) supplemented with 5\% fetal bovine serum (Atlanta Biologics, Lawrenceville, GA), $100 \mathrm{U} / \mathrm{ml}$ penicillin, $0.1 \mathrm{mg} / \mathrm{ml}$ streptomycin, $25 \mu \mathrm{g} / \mathrm{ml}$ amphotericin B (MP Biomedicals, Solon, OH), $0.5 \mathrm{~g} / 1$ potassium bicarbonate, $1 \mathrm{~g} / 1$ yeast extract (Sigma-Aldrich, St. Louis, MO) and $2.5 \mathrm{~g} / 1$ trypticase peptone (BD Biosciences, San Jose, CA) adjusted to $\mathrm{pH} 6.6$ with $1 \mathrm{M} \mathrm{KOH}(\mathrm{M} 3+\mathrm{BPYE})$. The cells were maintained at $26^{\circ} \mathrm{C}$ and subcultured every $3-4$ days. Subcultured cells were dislodged by aspiration, counted with a hemocytometer (Hauser and Son, Philadelphia, PN), and plated at a concentration of $1.5 \times 10^{6}$ cells per $\mathrm{ml}$ in $75 \mathrm{~cm}^{2}$ flasks.

For transfections, $18 \mu \mathrm{l}$ of Cellfectin was mixed with $1 \mu \mathrm{g}$ of plasmid DNA in $240 \mu 1$ of Grace's medium (both from Invitrogen, Grand Island, NY) and pre-incubated for $15 \mathrm{~min}$ at room temperature. Kc167 cells $\left(5 \times 10^{6}\right)$ were centrifuged at $1000 \mathrm{~g}$ for $5 \mathrm{~min}$ and resuspended in 2.5 $\mathrm{ml}$ of antibiotic- and serum-free M3+BPYE medium containing the plasmid DNA/Cellfectin mixture above and plated in 6-well plates (Corning Incorporated, Corning, NY). Stable cells for pAWG constructs were obtained by co-transfection with pCoPURO (Addgene plasmid 17533, Addgene, Cambridge, MA) at an expression plasmid to selection marker ratio of 1:20. The vector pAWG contains an actin promoter upstream of two recombination sites followed by a cterminal enhanced green fluorescent protein (GFP) construct and was designed by the Murphy laboratory (Carnegie Institution of Washington, Baltimore, MD). The vector is distributed by the Drosophila Genomics Resource Center (Indiana University, Bloomington, IN). The medium was exchanged with fully supplemented medium after $24 \mathrm{~h}$ and selective antibiotics were added after $48 \mathrm{~h}$. To select for stably transfected cells with constructs containing pIB/V-5-HIS-DEST, 50 $\mu \mathrm{g} / \mathrm{ml}$ blasticidine (Invitrogen, Grand Island, NY) was added, and for co-transfections with pCoPURO puromycin was used at $5 \mu \mathrm{g} / \mathrm{ml}$. Resistant cell lines were obtained after 2-4 weeks of selection, and successful transfection was confirmed by Western blotting in cases of pIB/V-5- 
HIS-DEST constructs or by microscopy in case of GFP-labeled proteins using pAWG/pCoPURO. Images were acquired with a Leica Microsystems TCS SP2 microscope equipped with a Plan Apo 63 N.A. 1.4 oil immersion lens. Two lasers, $488 \mathrm{~nm}$ at 15\% power and $543 \mathrm{~nm}$ at $25 \%$ power, were used to sequentially excite GFP and MitoTracker Red (Invitrogen, Grand Island, NY), respectively. Emission passes of 500-535 and 558-613 nm were used to detect the signals.

\subsection{SDS-PAGE and Western blot analyses}

About $10 \times 10^{6}$ cells were pelleted at $1000 \mathrm{~g}$ for $5 \mathrm{~min}$ and resuspended in $200 \mu \mathrm{l}$ of sample buffer (2\% SDS, 25\% glycerol, 5\% mercaptoethanol, $0.01 \%$ bromphenol blue, and $62.5 \mathrm{mM}$ Tris $\mathrm{HCl}, \mathrm{pH} 6.8$ ), denatured at $95^{\circ} \mathrm{C}$ for $5 \mathrm{~min}$ and $15-20 \mu \mathrm{l}$ of extract were loaded per lane. Samples containing cellular proteins were subjected to 10\% SDS-PAGE using a Bio-Rad MiniPROTEAN 3 Cell (Bio-Rad Laboratories, Hercules, CA). After electrophoresis, proteins in the gel were electrophoretically transferred with a Bio-Rad Mini Trans-Blot apparatus onto a nitrocellulose membrane $(0.2 \mu \mathrm{m}$, Bio-Rad) in a transfer buffer containing $192 \mathrm{mM}$ glycine, 20\% methanol, 0.025\% SDS, and $25 \mathrm{mM}$ Tris. Membranes were stained with Ponceau S to confirm transfer of the proteins. Blocking of membranes was performed for $1 \mathrm{~h}$ using $5 \%$ fat free dry milk in TBS-T (0.1\% Tween 20, $20 \mathrm{mM}$ Tris-HCl, $500 \mathrm{mM} \mathrm{NaCl,} \mathrm{pH} \mathrm{7.4).} \mathrm{Mouse} \mathrm{anti-V5}$ (ab27671; Abcam, Cambridge, MA) was used as primary antibody at 1:5,000 dilution. The blots were incubated overnight with the primary antibody in $5 \%$ BSA containing TBS-T at $4^{\circ} \mathrm{C}$. HRPlabeled goat anti-mouse IgG2a (ab97245) was used as secondary antibody at a dilution of 1:20,000. Proteins were visualized with LumiGlo following the protocol of the manufacturer (Cell Signaling Technology, Boston, MA) and recorded on Hyperfilm ECL (GE Healthcare, Piscataway, NJ).

\subsection{Respirometry}

Respiration was measured at $25^{\circ} \mathrm{C}$ using $5 \times 10^{6}$ log-phase cells in each respiratory chamber of an Oxygraph-2K (OROBOROS Instruments, Innsbruck, Austria). Respiration of nonpermeabilized cells was measured in M3+BPYE before and after addition of inhibitors or uncouplers. To induce hyperosmotic stress, cells were incubated on ice in M3+BPYE containing $500 \mathrm{mM}$ sucrose for $1 \mathrm{~h}$ prior to respirometry, and the same medium was used in the respiration 
chambers. The oxygen solubility coefficient of MiR05 was adjusted for the added sucrose (Hikita et al., 1978). Cellular respiration was uncoupled by successive titrations of carbonyl cyanide 4-(trifluoromethoxy) phenylhydrazone (FCCP; $0.5 \mu \mathrm{M}$ steps), and leak respiration was measured in the presence of oligomycin. DATLAB software (OROBOROS Instruments) was used for data analysis and acquisition. Oxygen flux $\left(\mathrm{JO}_{2} ; \mathrm{nmol} \mathrm{O}_{2} \mathrm{~s}^{-1} 10^{-6}\right.$ cells $)$ was calculated as the time derivative of oxygen concentration.

Oxygen consumption of permeabilized cells was measured in $2 \mathrm{ml}$ of MiR05 (110 mM sucrose, $60 \mathrm{mM}$ potassium lactobionate, $20 \mathrm{mM}$ taurine, $10 \mathrm{mM} \mathrm{KH}_{2} \mathrm{PO}_{4}, 3 \mathrm{mM} \mathrm{MgCl} 2,0.5 \mathrm{mM}$ EGTA, 0.1\% BSA, 20 mM HEPES-KOH, pH 7.1), and cells were permeabilized by addition of digitonin dissolved in DMSO at $10 \mathrm{mg} / \mathrm{ml}$ (final concentration $6 \mu \mathrm{g} \cdot 10^{-6}$ cells). This concentration was chosen after careful titrations with digitonin and found to be sufficient to permeabilize the plasma membrane with the lowest possible impact on the outer mitochondrial membrane (OMM). At a digitonin concentration of $6 \mu \mathrm{g} \cdot 10^{-6}$ cells additional injections of digitonin $\left(4 \mu \mathrm{g} \cdot 10^{-6}\right.$ cells) did not increase oxygen flux of adenosine diphosphate (ADP) stimulated respiration, and addition of cytochrome $c(10 \mu \mathrm{g} / \mathrm{ml})$ led to only minor increases in respiration rates. Mitochondrial substrates were supplied by adding $2 \mathrm{mM}$ malate, $10 \mathrm{mM}$ glutamate, $5 \mathrm{mM}$ pyruvate, and $10 \mathrm{mM}$ succinate. To induce oxidative phosphorylation (OXPHOS) $1 \mathrm{mM}$ ADP was added. Leak respiration in presence of ADP and ATP (LEAK $)$ was measured after addition of oligomycin $(2 \mu \mathrm{g} / \mathrm{ml})$ and respiration was uncoupled by successive titrations of $0.5 \mu \mathrm{M}$ FCCP. Contribution of Complex I to uncoupled respiration was recorded after addition of rotenone $(0.5 \mu \mathrm{M})$. In some experiments 10 successive $25 \mu 1$ injections of $4 \mathrm{M}$ $\mathrm{NaCl}$ or $\mathrm{KCl}$ (dissolved in MiR05), which equated to a total increase of $500 \mathrm{mM}$ salt in the chamber, were added in presence of substrates and ADP. The oxygen flux was corrected for the dilution of cells at each successive titration step. Residual oxygen consumption (nonmitochondrial respiration) was recorded after addition of $2.5 \mu \mathrm{M}$ of antimycin A.

\subsection{Respiratory capacity of isolated mitochondria pre- and post-freezing}

Mitochondria were isolated from Kc167 and Kc167-AfLEA1.3 cells by differential centrifugation after nitrogen cavitation with a cell disruption vessel following the protocol of the manufacturer (Parr Instrument Company, Moline, IL). Cultured cells were collected by centrifugation at $1000 \mathrm{~g}$ for $10 \mathrm{~min}$ at $4{ }^{\circ} \mathrm{C}$ and resuspended at a concentration of $40-60 \cdot 10^{6}$ 
cells $\cdot \mathrm{ml}^{-1}$ in ice-cold sucrose based isolation medium (400 mM sucrose, $0.5 \mathrm{mM}$ EDTA, 10 $\mathrm{mM}, 0.1 \%$ BSA, TRIS-HCl, $\mathrm{pH} 7.4$ ). About $10 \mathrm{ml}$ of the cell suspension was pressurized to 400 psi for 15 min at $4{ }^{\circ} \mathrm{C}$ and cells were disrupted by instant release from the chamber through a discharge valve after the incubation period. A sucrose concentration of $400 \mathrm{mM}$ in the isolation medium was found to disrupt most cells under these conditions and to preserve high mitochondrial RCR values. To separate mitochondria from cellular debris the homogenate was centrifuged for $10 \mathrm{~min}$ at $1,000 \mathrm{~g}$ and $4{ }^{\circ} \mathrm{C}$ and the supernatant was removed and centrifuged at $9,000 \mathrm{~g}$ for $15 \mathrm{~min}$ to pellet the mitochondrial fraction. To reduce osmotic stress to the mitochondria $50 \mathrm{mM}$ sucrose was added to MiR05 to reach $380 \mathrm{mOsM}$ (MiR05A) a value close to the osmolarity of D. melanogaster hemolymphe (Pierce et al., 1999), and the resulting pellet was gentle resuspended in ice-cold MiR05A and centrifuged again at 9,000 $\mathrm{g}$ for $10 \mathrm{~min}$. The final pellet was resuspended in $150-200 \mu \mathrm{l}$ MiR05A and contained $\sim 5 \mathrm{mg} / \mathrm{ml}$ protein. Mitochondrial protein was quantified using a Coomassie Plus Reagent Assay (Pierce, Rockford, IL), according to the manufacturer's instructions with BSA as the standard. Respiration measurements were performed first on fresh preparations using an Oxygraph-2K and about 10 $20 \mu 1$ of resuspended mitochondria per assay in MiR05A at $25^{\circ} \mathrm{C}$. Respiration was induced by adding $5 \mathrm{mM}$ pyruvate, $10 \mathrm{mM}$ proline and $2 \mathrm{mM}$ malate to provide electron flow through complex I (Pichaud et al., 2010). To engage the phosphorylation system $1 \mathrm{mM}$ ADP was added followed by additions of $10 \mathrm{mM}$ succinate and $10 \mathrm{mM}$ sn-glycerol-3-phosphate to supply electrons to the ubiquinone pool via succinate dehydrogenase and glycerol-3-phosphate dehydrogenase and to maximally reduce complex III. Leak respiration of energized mitochondria after addition of ADP $\left(\mathrm{LEAK}_{\mathrm{o}}\right)$ was measured in the presence of oligomycin $(2 \mu \mathrm{g} / \mathrm{ml})$. Next a $75 \mu \mathrm{l}$ aliquot of the mitochondrial suspension was transferred into a cryovial and placed into a passive freezing device (CoolCell, Biocision, Mill Valley, CA) which was stored at $-80{ }^{\circ} \mathrm{C}$ for at least $24 \mathrm{~h}$. Samples were thawed, placed on ice, and assayed for respiratory capacity as described above.

\subsection{Hyperosmotic stress and cell desiccation}

To assess the effect of osmotic stress on viability and proliferation, cells were grown in M3+BPYE at sucrose concentrations ranging from $0-200 \mathrm{mM}$. Cells were seeded at a density of $1 \times 10^{6}$ cells $/ \mathrm{ml}$ in 96-well microplates (Corning Incorporated, Corning, NY). Three wells of 
each treatment were plated per trial to account for well to well variation within the same population of cells. Microplates were wrapped in parafilm to prevent evaporation and placed at $26{ }^{\circ} \mathrm{C}$ for $48 \mathrm{~h}$. Aliquots of the cell suspension were removed $48 \mathrm{~h}$ after seeding, and the number of viable cells was directly determined by counting with a hemocytometer after 1:1 dilution of the sample with $0.4 \%$ trypan blue solution. The percentage of viable cells was calculated by dividing the number of cells with intact cell membranes in the treatment groups by the number of control cells with intact cell membranes observed at $0 \mathrm{mM}$ sucrose.

Desiccation tolerance of Kc167 control cells and those cells expressing AfLEA1.3 was investigated by convective drying in droplets. Immediately prior to the desiccation experiments, cells were pelleted by centrifugation and re-suspended in M3+BPYE containing $200 \mathrm{mM}$ trehalose. Trehalose was added to confer protection to the plasma membrane during desiccation; viability of cells dried without trehalose was very poor (data not shown). Cells were washed once with $10 \mathrm{ml}$ of this medium prior to re-suspension of the cells at a dilution of 20-25 x 10 6 cells $/ \mathrm{ml}$. Ten $15 \mu$ d droplets of cell suspension were pipetted onto $35 \mathrm{~mm}$ tissue culture dishes and placed in a desiccation cabinet at ambient temperature $\left(22-24{ }^{\circ} \mathrm{C}\right)$ containing Drierite (W.A. Drierite Co., Xenia, $\mathrm{OH})$. Samples were dried to a range of final moisture contents as determined gravimetrically. Water content was expressed as grams water per gram of dry mass. Sample dry mass was determined by drying parallel samples for $24 \mathrm{~h}$ at $60{ }^{\circ} \mathrm{C}$. Upon reaching the target moisture content, samples were then immediately rehydrated with excess M3+BYPE and incubated at $26^{\circ} \mathrm{C}$ overnight. Membrane integrity was determined by trypan blue exclusion (BD Biosciences, San Jose, CA). To quantify dehydration tolerance, cell counts after drying and recovery were normalized to cell counts obtained for samples that were treated identically but never dried.

\subsection{Bioinformatics and statistical analyses}

The Kyte Doolittle algorithm was used to construct the hydropathy plot using ExPASy ProtScale (http://www.expazy/tools). The hydropathy plot was computed with a 9-residue moving average. Subcellular localization of proteins was predicted using MitoProt II (http://ihg.gsf.de/ihg/mitoprot.html), TargetP, WolfPsort, and Predotar (http://www.psort.org/). Statistical significance among groups was evaluated with a one-way ANOVA on ranks followed by the Student-Newman-Keuls method (for groups with equal sample sizes) or Dunn's test (for 
groups with unequal sample sizes) for all pair-wise comparison of means. To analyze the response of cell lines to desiccation, an ANCOVA was performed using cell line (transformed vs. untransformed) as a categorical variable and water content as a continuous variable. The interaction term between cell line and water content in this model tests whether the viability responses of the two lines are similar. For simple comparisons between two groups the student's t-test was used. Significance level was set at $\mathrm{p} \leq 0.05$. Statistic analyses were performed with SigmaPlot $\subset$ for Windows Version 12.3 (SPSS Inc., Chicago, IL). 


\section{RESULTS}

Two unique nucleotide sequences (AfLEA-1.1 and AfLEA-1.3) were amplified from diapause embryos of Artemia franciscana with primers based on a previously-published sequence for a group 1 LEA gene (Sharon et al., 2009). The sequences encode for polypeptides of 180 and 197 amino acids, respectively, and both share approximately 86\% sequence homology to the previously published protein sequence (Gene Bank: ABR67402). The encoded proteins are nearly identical with the exception that AfLEA1.3 contains a stretch of 17 additional amino acids within the deduced mitochondrial leader sequence at the N-terminus (Fig. 1A). In Kyte-Doolittle hydrophobicity plots both proteins scored well below zero demonstrating the highly hydrophilic nature of the protein (Fig. 1B), which is a main feature of typical LEA proteins (Battaglia et al., 2008). Based on bioinformatics software the probabilities of mitochondrial localization estimated for AfLEA1.1 and AfLEA1.3 are 89\%, 94\% (MitoProt II), 67\%, 94\% (Target P), 45\%, 82\% (Wolf Psort), and 10\%, 6\% (Predotar), respectively. Although AfLEA1.3 scores higher with most programs used, both proteins exhibit likelihood for mitochondrial targeting.

The program MitoProt II predicted that AfLEA1.3 contains an N-terminal pre-sequence of 36 amino acids that is likely to be cleaved after the protein is imported into the mitochondrion. However, a cleavage site could not be located for AfLEA1.1. In order to determine subcellular localization, GFP-LEA constructs for both proteins were expressed in Kc167 cells from $D$. melanogaster. Confocal images revealed that AfLEA1.1-GFP localized to the cytoplasmic compartment, while AfLEA1.3-GFP accumulated within mitochondria (Fig. 2). Thus, the Nterminal sequence of 17 amino-acids present in AfLEA1.3, but lacking in AfLEA1.1, is necessary for import into the mitochondrion.

\subsection{Respiration of non-permeabilized cells, permeabilized cells, and isolated mitochondria}

Significant differences in routine respiration of non-permeabilized cells were not detected between Kc167 control cells and cells expressing AfLEA1.3 when measured in standard culture medium. Cells were challenged with acute hyperosmotic stress by adding $500 \mathrm{mM}$ sucrose to the culture medium, and both cell lines exhibited significant reductions in routine respiration of about $40 \%$ compared to controls $(n=4-8, \mathrm{p} \leq 0.05$; Table 1$)$. Upon inhibition of the $\mathrm{F}_{0} \mathrm{~F}_{1}$ ATPase with oligomycin $(2 \mu \mathrm{g} / \mathrm{ml})$, leak respiration rates in presence and absence of $500 \mathrm{mM}$ 
sucrose were significantly lower in cells expressing AfLEA1.3, a pattern which was also reflected in the higher ratio of routine to leak respiration (Table 1). Western blot analysis with a monoclonal antibody raised against the V5 epitope confirmed expression of AfLEA1.3 by detecting a band with an apparent molecular weight of $\sim 30 \mathrm{kDa}$ in extracts from Kc167AfLEA1.3 cells but not in control cells (Fig. 3). The apparent molecular weight estimated by Western blotting is in close approximation to the molecular mass calculated for the full length protein including the V5 epitope and leader sequence $(\sim 26 \mathrm{kDa})$, but is substantially above the weight of the proposed mature protein after cleavage of the mitochondrial targeting sequence $(\sim 22.5 \mathrm{kDa})$. However, the cleavage site is only predicted by bioinformatics and has not been identified experimentally. The apparent molecular weight of some intrinsically disordered proteins estimated by SDS PAGE is often 1.2 to 1.8 times higher than the molecular mass calculated from the amino acid sequence (Tompa, 2002).

A typical titration protocol employed with permeabilized cells is shown in Figure 4A. Oxygen flux of permeabilized $\mathrm{Kc} 167$ control cells was $7.9 \pm 0.7 \mathrm{pmol} \mathrm{O} \mathrm{O}_{2} \cdot \mathrm{s}^{-1} \cdot 10^{-6}$ cells after the addition of substrates that lead to electron entry at complex I (malate+glutamate+pyruvate). This value was indistinguishable from cells expressing AfLEA1.3 $\left(7.3 \pm 0.4 \mathrm{pmol} \mathrm{O}_{2} \cdot \mathrm{s}^{-1} \cdot 10^{-6}\right.$ cells $)$. Both cell lines showed approximately $28 \%$ increases in respiration rate after addition of $5 \mathrm{mM}$ succinate, which promotes convergent electron entry from complex II into the ubiquinone pool (Fig. 5b). To demonstrate that sufficient permeabilization of the plasma membrane had been attained without compromising the integrity of the outer mitochondrial membrane, injections of cytochrome- $c$ (Fig. 4A) and additional digitonin (data not shown) were performed; neither increased maximum oxygen flux after ADP addition. In contrast to experiments with intact cells, leak respiration rates observed after inhibition of the $F_{0} F_{1}$-ATPase with oligomycin $(2 \mu \mathrm{g} / \mathrm{ml})$ were indistinguishable between cell lines after permeabilization. Oxygen consumption was uncoupled from the phosphorylation system by titration with the protonophore FCCP in $0.5 \mu \mathrm{M}$ steps. Surprisingly, control cells reached a significantly higher rate $\left(22.9 \pm 0.2 \mathrm{pmol} \mathrm{O}_{2} \cdot \mathrm{s}^{-1} \cdot 10^{-}\right.$ ${ }^{6}$ cells) than cells expressing AfLEA1.3 $\left(17.7 \pm 0.9 \mathrm{pmol} \mathrm{O}_{2} \cdot \mathrm{s}^{-1} \cdot 10^{-6}\right.$ cells; mean \pm s.e.m., $n=$ 6-7, $\mathrm{p} \leq 0.05$; Fig. 4B). Decreasing the FCCP concentration did not improve the uncoupled rate which suggests that FCCP failed to fully uncouple the mitochondria and actually inhibited respiration. However, titrations of low amounts of FCCP to permeabilized cells in presence of substrates and ADP failed to increase oxygen consumption before the onset of inhibition which 
may indicates that the electron transport system was working close to maximum capacity under these experimental conditions (data not shown) ${ }^{1}$. Interestingly, ADP-induced respiration in permeabilized cells was only $53 \%$ higher than routine respiration of intact cells which indicates that respiration in intact cells was likely substrate limited and operated to satisfy an intermediate ATP demand (Brand and Nicholls, 2011).

To evaluate the influence of AfLEA1.3 on mitochondrial bioenergetics during hyperosmotic salt stress, ADP-stimulated oxygen flux of permeabilized cells was measured during 10 successive injections of $\mathrm{NaCl}$ or $\mathrm{KCl}$ (Fig. 5). Each injection increased the salt concentration by $50 \mathrm{mM}$. Maximal inhibition of oxygen flux was $64.9 \pm 2.6 \%$ for control cells in presence of $\mathrm{NaCl}$, and this inhibition was markedly ameliorated to $53.8 \pm 2.6 \%(n=4, \pm$ s.e.m.) in cells expressing AfLEA1.3 (Table 2). Significant differences were not detected between cell lines when titrations were performed with $\mathrm{KCl}$.

AfLEA1.3 is synthesized on cytoplasmic ribosomes and the cytoplasmic fraction of the protein might contribute to some of the effects on mitochondrial functions observed in respirometry on intact and permeabilized cells. Furthermore, isolated mitochondria from the brine shrimp A. franciscana show a remarkable tolerance to water stress in form of freezing, a phenomenon that might be partially due to the presence of mitochondrial LEA proteins (Menze et al., 2009). To test the impact of AfLEA1.3 on freeze-tolerance of the organelle, mitochondria were isolated from both cell lines and cooled to $-80{ }^{\circ} \mathrm{C}$ at a rate of $1{ }^{\circ} \mathrm{C}$ per minute. Isolated mitochondria from both cell lines did not differ under any condition assayed prior to freezing and showed a high respiratory control ratio (RCR) of $11.27 \pm 1.4$ (mean \pm s.e.m., $n=8, \mathrm{p}>0.05$ ). Oxygen consumption in presence of ADP and substrates that supply NADH to complex I were significantly reduced after freezing and thawing for mitochondria from both cell lines (Fig. 6). However, this reduction was significantly greater in mitochondria from control cells $(\mathrm{RCR}=$ $7.34 \pm 1.03$, mean \pm s.e.m., $n=4)$ than in cells expressing AfLEA1.3 $(\mathrm{RCR}=10.1 \pm 0.7$, mean \pm s.e.m., $n=4, \mathrm{p}<0.05$ ), which maintained higher respiratory capacities with all substrate combinations employed under conditions that promote oxidative phosphorylation (Fig. 6).

\subsection{Tolerance to osmotic stress and desiccation conferred to Kc167 cells by AfLEA1.3.}

Water-stress tolerance of both control cells and cells expressing AfLEA1.3 were investigated using two independent experimental procedures. First, cells were cultured in presence of 
increasing concentrations of the non-permeable solute sucrose, and after $48 \mathrm{~h}$ of incubation the cell viability was determined (expressed as a percentage of the number of viable cells counted in control cultures without sucrose). Expression of AfLEA1.3 conferred a protective effect against osmotic stress as documented by significantly higher viabilities for Kc167-AfLEA1.3 cells compared to wild-type Kc167 cells for all sucrose concentrations tested ( $n=9, \mathrm{p} \leq 0.05$ ). Second, cells suspended in a medium containing $200 \mathrm{mM}$ trehalose were dried in a low-humidity chamber for various times to achieve a wide range of moisture contents $\left(\mathrm{g}_{2} \mathrm{O} / \mathrm{g}\right.$ DW). After rehydration in fully supplemented medium without trehalose and culture for $24 \mathrm{~h}$, cell viability was measured. The viability of all cells decreased with decreasing moisture content (Fig. 8). However, linear regression resolved two significantly different slopes of $5.6 \pm 0.4\left(r^{2}=0.79\right)$ for control cells and $13.5 \pm 0.9\left(r^{2}=0.70\right)$ for cells expressing AfLEA1.3. The expression of AfLEA1.3 resulted in a statistically significant change in the viability response to water content (ANCOVA: F1,132 $=49.69, \mathrm{P}<0.0001, \mathrm{r}^{2}=0.74$ ), consistent with the results of the individual nonlinear regressions (Fig. 8). Furthermore, the lowest moisture levels at which viable cells were found decreased from $1.02 \mathrm{~g} \mathrm{H}_{2} \mathrm{O} / \mathrm{g}$ DW for control cells to $0.36 \mathrm{~g} \mathrm{H}_{2} \mathrm{O} / \mathrm{g} \mathrm{DW}$ for cells expressing AfLEA1.3 (Fig. 8). Thus, the expression of AfLEA1.3 protected Kc167 cells during air drying. 


\section{DISCUSSION}

We have demonstrated in this study that the transgenic expression of a mitochondrial targeted LEA protein (AfLEA1.3) in desiccation-sensitive cells from the fruit fly $D$. melanogaster improves cell viability under hyperosmotic conditions and in response to convective air-drying. Furthermore, non-permeabilized cells that expressed AfLEA1.3 exhibited reductions of $20-30 \%$ in proton leak across the inner mitochondrial membrane in the presence and absence of hyperosmotic stress, as compared to controls cells without AfLEA1.3. For permeabilized cells, the inhibition of respiration in presence of ADP and substrates as a result of hyperosmotic $\mathrm{NaCl}$ exposure was ameliorated by about $18 \%$ in AfLEA1.3 cells compared to controls. In cases of moderate water and salt stress, AfLEA1.3 provided protection even under hydration states when the protein is most likely intrinsically disordered (Figs. 5, 7). Consequently, the folded conformation of LEA proteins is not always required to confer protection against water stress.

AfLEA1.1 and AfLEA1.3 are nearly identical except for 17 additional amino acids located near the N-terminus of AfLEA1.3. All mitochondrial matrix proteins are encoded by nuclear genes and are transported across the outer and inner mitochondrial membrane after being synthesized by cytoplasmic ribosomes ((Attardi and Schatz, 1988; Chacinska et al., 2009; Lemire et al., 1989; Schmidt et al., 2010). Similar to other proteins destined for the matrix, AfLEA1.3 contains a positively charged N-terminal pre-sequence; the projected cleavage site is after amino-acid position 36 but has not been experimentally confirmed. Several LEA proteins belonging to groups 3 and 4 are predicted to reside in mitochondria of the plant Arabidopsis thaliana (Hundertmark and Hincha, 2008). Furthermore, a group 3 LEA protein from pea seeds (PsLEAm) is imported into the mitochondrial matrix and protects mitochondrial matrix enzymes from activity loss and artificial liposomes from vesicle fusion during in vitro desiccation experiments (Grelet et al., 2005; Tolleter et al., 2010; Tolleter et al., 2007). Anhydrobiotic animals apparently have developed similar strategies to survive water loss; multiple LEA proteins belonging to groups 1 and 3 are present in mitochondria of A. franciscana embryos (Menze et al., 2009; Warner et al., 2010). We can only speculate about the reasons for multiple mitochondrial LEA proteins in anhydrobiotic organisms. Attractive scenarios include different spatial distribution within the organelle or preferred interactions with different classes of macromolecules. The latter case has been documented for two highly similar LEA proteins from 
Adineta riccia, ArLEA1A and ArLEA1B, which carry retention signal sequences for the endoplasmic reticulum. Both proteins were found to differ only by an internal stretch of 44 amino acids (four 11-mer repeats) found in ArLEA1B but absent in ArLEA1A. Surprisingly, the additional 11-mer repeats changed the properties of ArLEA1B so that it decreased the gel-toliquid crystalline phase-transition temperature of dried palmitoyl-oleoyl-phosphotidylcholine; this property was absent for ArLEA1A. These findings suggest that these proteins interact preferentially with proteins or lipids, despite being highly similar (Pouchkina-Stantcheva et al., 2007; Tripathi et al., 2012).

When water is removed, most LEA proteins assume their 'native' conformation, which often consists of a high percentage of $\alpha$-helix (for reviews see (Hand et al., 2011; Tunnacliffe and Wise, 2007)). For example, molecular dynamics simulation of a LEA protein fragment from the nematode Aphelenchus avenae showed no substantial increase in $\alpha$-helix during reductions in the protein water content from 80 to $30 \mathrm{wt} \%$. The protein retained its random coil structure across this range ( $\mathrm{Li}$ and $\mathrm{He}, 2009$ ). Yet specific functions have been reported for LEA proteins even in the hydrated state. For example, transgenic expression of LEA proteins increases drought tolerance in some plant species (Babu et al., 2004; Iturriaga et al., 1992; Maqbool et al., 2002; Sivamani et al., 2000). Drought tolerance describes survival during moderate dehydration, with low bulk cytoplasmic water (Hoekstra et al., 2001), which may be insufficient water removal to trigger the native conformation of LEA proteins. In this context, a number of reports document that LEA proteins from animal species can prevent aggregation of target proteins in vivo in the complete absence of water stress. An animal group 3 LEA protein from A. avenea (AavLEA1) reduced protein aggregation when co-expressed with self-aggregating polyglutamin proteins or amyloid $\beta$-peptide (Chakrabortee et al., 2012; Liu et al., 2011) and chaperone activity was demonstrated for group 2 LEA proteins from A. thaliana (Kovacs et al., 2008). Apparently, some LEA proteins provide cellular protection to plants and animals during water stress despite being mostly intrinsically disordered at these high water contents.

In the present study, we found that under control conditions and in response to $500 \mathrm{mM}$ sucrose, non-permeabilized cells expressing mitochondrial-targeted LEA protein had statistically significantly lower leak respiration than cells without LEA protein (Table 1). We did not observe lower leak respiration in permeabilized AfLEA1.3 expressing cells compared to control (Fig. 4). This result was unexpected and might be due to treatment with digitonin or the high substrate 
concentrations that are used to energize mitochondria in permeabilized cells. Leak respiration rates in presence of high substrate concentrations were also identical for isolated mitochondria from both cell lines (Fig. 6) and matched well with respiration rates measured for mitochondria isolated from D. simulans flight muscle (Pichaud et al., 2010). Similar to mitochondria isolated from A. franciscana embryos (Menze et al., 2009) a high capacity to maintain functional integrity after freeze-thawing in presence of polyols (trehalose or sucrose) was observed for mitochondria isolated from Kc167-AfLEA1.3 cells. The observed functional integrity after freezing is quite remarkable. In contrast, mouse liver mitochondria that naturally lack LEA proteins show a dramatic reduction in the respiratory control ratio after freeze-thawing in trehalose containing medium (Yamaguchi et al., 2007). Viability for non-permeabilized cells expressing AfLEA1.3 was higher in the presence of increasing concentrations of sucrose compared to control cells (Fig. 7). Again, these modest degrees of water stress are unlikely to promote substantial coiling of LEA proteins as judged by several in vitro models (Furuki et al., 2011; Hundertmark et al., 2012; Li and He, 2009; Popova et al., 2011). Thus AfLEA1.3 may interact in some fashion with proteins or membranes in the uncoiled state. A similar conclusion can be reached for the ability of AfLEA1.3 to ameliorate the impact of salt stress on mitochondrial function in Figure 5. Protection against salt and osmotic stress by transgenic expression of plant LEA proteins has also been demonstrated in yeast and bacteria (Lan et al., 2005; Yu, 2005). Furthermore, the glucose starvation-inducible protein B (GsiB; Bacillus subtilis) shows high similarities with group 1 LEA proteins (Stacy and Aalen, 1998) and GsiB domain carrying proteins are involved in high-salt tolerant Escherichia coli strains (Kapardar et al., 2010).

It is appropriate to note that the above examples, which illustrate the protection afforded by hydrated LEA proteins, do not preclude even greater stabilization of biological structure and function in the dried state. As previously noted, it has been well demonstrated that LEA proteins gain secondary structure when water is removed (Furuki et al., 2011; Li and He, 2009), and thus their functions might be more evident, and even qualitatively different, at water contents below most of the ones studied here. Nevertheless, it is becoming clear that LEA proteins exhibit specific functions at hydration states that most likely lack extensive secondary structure in vivo and thus can operate outside the classic structure-function paradigm (cf. (Uversky and Dunker, 2010)). 


\section{FUNDING}

This research was funded by the National Science Foundation (grant IOS-0920254) to M.A.M and S.C.H., an Eastern Illinois University Council on Faculty research (CFR) grant to M.A.M., and Eastern Illinois University Honors College Undergraduate Research, Scholarship, and Creative Activities grants (URSCA) to M.R.M.

\section{${ }^{1}$ FOOTNOTE}

It is well known that high concentrations carbonyl cyanide 4-(trifluoromethoxy) phenylhydrazone (FCCP) can inhibit respiration rates in mammalian models (SteinlechnerMaran et al., 1996) and careful titrations are necessary to yield maximal rates in the uncoupled state. However, sometimes uncoupled rates were below ADP-stimulated rates despite testing a wide range of concentrations and uncouplers including FCCP, carbonyl cyanide 3chlorophenylhydrazone (CCCP), dinitrophenol (DNP), and 3,5-di-tert-butyl-4-hydroxybenzylid (malonaben). This effect was in some cases pronounced in presence of oligomycin. The reason for the high sensitivity of Drosophila mitochondria to the inhibitory effects of these chemicals is unknown. 


\section{REFERENCES}

Attardi, G., Schatz, G., 1988. Biogenesis of mitochondria. Annual Review of Cell Biology 4, 289-333.

Babu, R., Zhang, J., Blum, A., Ho, T., Wu, R., Nguyen, H., 2004. HVA1, a LEA gene from barley confers dehydration tolerance in transgenic rice (Oryza sativa L.) via cell membrane protection. Plant Science 166, 7.

Battaglia, M., Olvera-Carrillo, Y., Garciarrubio, A., Campos, F., Covarrubias, A.A., 2008. The enigmatic LEA proteins and other hydrophilins. Plant Physiology 148, 6-24.

Billi, D., Potts, M., 2002. Life and death of dried prokaryotes. Research in Microbiology 153, 712.

Brand, M.D., Nicholls, D.G., 2011. Assessing mitochondrial dysfunction in cells. Biochemistry Journal 435, 297-312.

Bray, E.A., 1993. Molecular Responses to Water Deficit. Plant Physiology 103, 1035-1040.

Chacinska, A., Koehler, C.M., Milenkovic, D., Lithgow, T., Pfanner, N., 2009. Importing mitochondrial proteins: machineries and mechanisms. Cell 138, 628-644.

Chakrabortee, S., Liu, Y., Zhang, L., Matthews, H.R., Zhang, H., Pan, N., Cheng, C.R., Guan, S.H., Guo, D.A., Huang, Z., Zheng, Y., Tunnacliffe, A., 2012. Macromolecular and smallmolecule modulation of intracellular Abeta42 aggregation and associated toxicity. Biochemistry Journal 442, 507-515.

Clegg, J.S., 1973. Do dried cryptobiotes have a metabolism?, Anhydrobiosis. Dowden, Hutchinson and Ross, Stroudsbourg, PA, p. 5.

Clegg, J.S., 2001. Cryptobiosis--a peculiar state of biological organization. Comparative Biochemistry and Physiology Part B: Biochemistry and Molecular Biology 128, 613-624.

Crowe, J.H., Clegg, J.S., 1973. Anhydrobiosis. Dowden, Stroudsburg, Pa.,.

Crowe, J.H., Hoekstra, F.A., Crowe, L.M., 1992. Anhydrobiosis. Annual Review of Physiology 54, 579-599.

Crowe, J.H., Madin, K.A.C., 1974. Anhydrobiosis in tardigrades and nematodes. Transactions of the American Microscopical Society 93, 11.

Crowe, J.H., Madin, K.A.C., 1975. Anhydrobiosis in nematodes: evaporative water loss and survival. Journal of Experimental Zoology 193, 11.

Cuming, A., 1999. LEA proteins, in: Shewry, P., Casey, R. (Eds.), Seed Proteins. Kluwer Acad., Dordrecht, Netherlands, p. 27.

Dure, L., Galau, G.A., 1981. Developmental Biochemistry of Cottonseed Embryogenesis and Germination : XIII. REGULATION OF BIOSYNTHESIS OF PRINCIPAL STORAGE PROTEINS. Plant Physiology 68, 187-194.

Espelund, M., Saeboe-Larssen, S., Hughes, D.W., Galau, G.A., Larsen, F., Jakobsen, K.S., 1992. Late embryogenesis-abundant genes encoding proteins with different numbers of hydrophilic repeats are regulated differentially by abscisic acid and osmotic stress. The Plant Journal 2, 241252.

Furuki, T., Shimizu, T., Kikawada, T., Okuda, T., Sakurai, M., 2011. Salt Effects on the structural and thermodynamic properties of a group 3 LEA protein model peptide. Biochemistry 50, 7093-7103.

Galau, G.A., Hughes, D. W., and Dure, L., III, 1986. Abscisic acid induction of cloned cotton late embryogenesis-abundant (lea) mRNAs. Plant Molecular Biology 7, 15.

Goyal, K., Walton, L.J., Browne, J.A., Burnell, A.M., Tunnacliffe, A., 2005. Molecular anhydrobiology: identifying molecules implicated in invertebrate anhydrobiosis. Integrative and Comparative Biology 45, 702-709. 
Grelet, J., Benamar, A., Teyssier, E., Avelange-Macherel, M.H., Grunwald, D., Macherel, D., 2005. Identification in pea seed mitochondria of a late-embryogenesis abundant protein able to protect enzymes from drying. Plant Physiology 137, 157-167.

Hand, S.C., Jones, D., Menze, M.A., Witt, T.L., 2007. Life without water: expression of plant LEA genes by an anhydrobiotic arthropod. Journal of Experimental Zoology Part A: Ecological Genetics and Physiology 307, 62-66.

Hand, S.C., Menze, M.A., Toner, M., Boswell, L., Moore, D., 2011. LEA proteins during water stress: not just for plants anymore. Annual Review of Physiology 73, 115-134.

Hikita, H., Asai, S., Azuma, Y., 1978. Solubility and diffusivity of oxygen in aqueous sucrose solutions. The Canadian Journal of Chemical Engineering 56, 3.

Hinton, H.E., 1968. Reversible suspension of metabolism and the origin of life. Proceedings of the Royal Society B: Biological Sciences 171, 43-57.

Hoekstra, F.A., Golovina, E.A., Buitink, J., 2001. Mechanisms of plant desiccation tolerance. Trends in Plant Science 6, 431-438.

Hundertmark, M., Hincha, D.K., 2008. LEA (late embryogenesis abundant) proteins and their encoding genes in Arabidopsis thaliana. BMC Genomics 9, 118.

Hundertmark, M., Popova, A.V., Rausch, S., Seckler, R., Hincha, D.K., 2012. Influence of drying on the secondary structure of intrinsically disordered and globular proteins. Biochemical and Biophysical Research Communications 417, 122-128.

Iturriaga, G., Schneider, K., Salamini, F., Bartels, D., 1992. Expression of desiccation-related proteins from the resurrection plant Craterostigma plantagineum in transgenic tobacco. Plant Molecular Biology 20, 555-558.

Kapardar, R.K., Ranjan, R., Grover, A., Puri, M., Sharma, R., 2010. Identification and characterization of genes conferring salt tolerance to Escherichia coli from pond water metagenome. Bioresource Technology 101, 3917-3924.

Keilin, D., 1959. The problem of anabiosis or latent life: history and current concept. Proceedings of the Royal Society B: Biological Sciences 150, 149-191.

Kovacs, D., Kalmar, E., Torok, Z., Tompa, P., 2008. Chaperone activity of ERD10 and ERD14, two disordered stress-related plant proteins. Plant Physiology 147, 381-390.

Lan, Y., Cai, D., Zheng, Y., 2005. Expression in Escherichia coli of Three Different Soybean Late Embryogenesis Abundant (LEA) Genes to Investigate Enhanced Stress Tolerance. Journal of Integrative Plant Biology 47, 8.

Lemire, B.D., Fankhauser, C., Baker, A., Schatz, G., 1989. The mitochondrial targeting function of randomly generated peptide sequences correlates with predicted helical amphiphilicity. Journal of Biological Chemistry 264, 20206-20215.

Li, D., He, X., 2009. Desiccation induced structural alterations in a 66-amino acid fragment of an anhydrobiotic nematode late embryogenesis abundant (LEA) protein. Biomacromolecules 10, 1469-1477.

Liu, Y., Chakrabortee, S., Li, R., Zheng, Y., Tunnacliffe, A., 2011. Both plant and animal LEA proteins act as kinetic stabilisers of polyglutamine-dependent protein aggregation. FEBS Letters 585, 630-634.

Maqbool, B., Zhong, H., El-Maghraby, Y., Ahmad, A., Chai, B., Wang, W., Sabzikar, R., Sticklen, B., 2002. Competence of oat (Avena sativa L.) shoot apical meristems for integrative transformation, inherited expression, and osmotic tolerance of transgenic lines containing hval. Theoretical and Applied Genetics 105, 201-208. 
Menze, M.A., Boswell, L., Toner, M., Hand, S.C., 2009. Occurrence of mitochondria-targeted Late Embryogenesis Abundant (LEA) gene in animals increases organelle resistance to water stress. Journal of Biological Chemistry 284, 10714-10719.

Oliver, A.E., Leprince, O., Wolkers, W.F., Hincha, D.K., Heyer, A.G., Crowe, J.H., 2001. NonDisaccharide-Base Mechanisms of Protection during Drying. Cryobiology 43, 16.

Pammenter, N.W., Berjak, P., 1999. A review of recalcitrant seed physiology in relation to desiccation-tolerance mechanisms. Seed Science Research 9, 24.

Pichaud, N., Chatelain, E.H., Ballard, J.W., Tanguay, R., Morrow, G., Blier, P.U., 2010. Thermal sensitivity of mitochondrial metabolism in two distinct mitotypes of Drosophila simulans: evaluation of mitochondrial plasticity. Journal of Experimental Biology 213, 1665-1675.

Pierce, V.A., Mueller, L.D., Gibbs, A.G., 1999. Osmoregulation in Drosophila melanogaster selected for urea tolerance. Journal of Experimental Biology 202, 2349-2358.

Popova, A.V., Hundertmark, M., Seckler, R., Hincha, D.K., 2011. Structural transitions in the intrinsically disordered plant dehydration stress protein LEA7 upon drying are modulated by the presence of membranes. Biochimica et Biophysica Acta 1808, 1879-1887.

Potts, M., 1999. Mechanisms of desiccation tolerance in cyanobacteria. European Journal of Phycology 34, 9.

Pouchkina-Stantcheva, N.N., McGee, B.M., Boschetti, C., Tolleter, D., Chakrabortee, S., Popova, A.V., Meersman, F., Macherel, D., Hincha, D.K., Tunnacliffe, A., 2007. Functional divergence of former alleles in an ancient asexual invertebrate. Science 318, 268-271.

Reynolds, J.A., Hand, S.C., 2004. Differences in isolated mitochondria are insufficient to account for respiratory depression during diapause in artemia franciscana embryos. Physiological and Biochemical Zoology 77, 366-377.

Schmidt, O., Pfanner, N., Meisinger, C., 2010. Mitochondrial protein import: from proteomics to functional mechanisms. Nature Reviews Molecular Cell Biology 11, 655-667.

Sharon, M.A., Kozarova, A., Clegg, J.S., Vacratsis, P.O., Warner, A.H., 2009. Characterization of a group 1 late embryogenesis abundant protein in encysted embryos of the brine shrimp Artemia franciscana. Biochemistry and Cell Biology 87, 415-430.

Shih, M.D., Hoekstra, F.A., Hsing, Y.I.C., 2008. Late embryogenesis abundant proteins. Advances in Botanical Research 48, 44.

Sivamani, E., Bahieldin, A., Wraith, J.M., Al-Niemi, T., Dyer, W.E., Ho, T.D., Qu, R., 2000. Improved biomass productivity and water use efficiency under water deficit conditions in transgenic wheat constitutively expressing the barley HVA1 gene. Plant Science 155, 1-9.

Solomon, A., Salomon, R., Paperna, I., Glazer, I., 2000. Desiccation stress of entomopathogenic nematodes induces the accumulation of a novel heat-stable protein. Parasitology 121 ( Pt 4), 409416.

Stacy, R.A., Aalen, R.B., 1998. Identification of sequence homology between the internal hydrophilic repeated motifs of group 1 late-embryogenesis-abundant proteins in plants and hydrophilic repeats of the general stress protein GsiB of Bacillus subtilis. Planta 206, 476-478.

Steinlechner-Maran, R., Eberl, T., Kunc, M., Margreiter, R., Gnaiger, E., 1996. Oxygen dependence of respiration in coupled and uncoupled endothelial cells. American Journal of Physiology 271, C2053-2061.

Steponkus, P.L., Uemura, M., Joseph, R.A., Gilmour, S.J., Thomashow, M.F., 1998. Mode of action of the COR15a gene on the freezing tolerance of Arabidopsis thaliana. Proceedings of the National Academy of Sciences U S A 95, 14570-14575. 
Stupnikova, I., Benamar, A., Tolleter, D., Grelet, J., Borovskii, G., Dorne, A.J., Macherel, D., 2006. Pea seed mitochondria are endowed with a remarkable tolerance to extreme physiological temperatures. Plant Physiology 140, 326-335.

Tolleter, D., Hincha, D.K., Macherel, D., 2010. A mitochondrial late embryogenesis abundant protein stabilizes model membranes in the dry state. Biochimica et Biophysica Acta 1798, 19261933.

Tolleter, D., Jaquinod, M., Mangavel, C., Passirani, C., Saulnier, P., Manon, S., Teyssier, E., Payet, N., Avelange-Macherel, M.H., Macherel, D., 2007. Structure and function of a mitochondrial late embryogenesis abundant protein are revealed by desiccation. Plant Cell 19, 1580-1589.

Tompa, P., 2002. Intrinsically unstructured proteins. Trends in Biochemical Sciences 27, 527533.

Tripathi, R., Boschetti, C., McGee, B., Tunnacliffe, A., 2012. Trafficking of bdelloid rotifer late embryogenesis abundant proteins. Journal of Experimental Biology 215, 2786-2794.

Tunnacliffe, A., Lapinski, J., 2003. Resurrecting Van Leeuwenhoek's rotifers: a reappraisal of the role of disaccharides in anhydrobiosis. Philosophical Transactions of the Royal Society B: Biological Sciences 358, 1755-1771.

Tunnacliffe, A., Wise, M.J., 2007. The continuing conundrum of the LEA proteins. Naturwissenschaften 94, 791-812.

Uversky, V.N., Dunker, A.K., 2010. Understanding protein non-folding. Biochimica et Biophysica Acta 1804, 1231-1264.

Warner, A.H., Miroshnychenko, O., Kozarova, A., Vacratsis, P.O., MacRae, T.H., Kim, J., Clegg, J.S., 2010. Evidence for multiple group 1 late embryogenesis abundant proteins in encysted embryos of Artemia and their organelles. Journal of Biochemistry 148, 581-592.

Watanabe, M., Kikawada, T., Fujita, A., Okuda, T., 2005. Induction of anhydrobiosis in fat body tissue from an insect. Journal of Insect Physiology 51, 727-731.

Wise, M.J., 2003. LEAping to conclusions: a computational reanalysis of late embryogenesis abundant proteins and their possible roles. BMC Bioinformatics 4, 52.

Wise, M.J., Tunnacliffe, A., 2004. POPP the question: what do LEA proteins do? Trends in Plant Science 9, 13-17.

Wolkers, W.F., McCready, S., Brandt, W.F., Lindsey, G.G., Hoekstra, F.A., 2001. Isolation and characterization of a D-7 LEA protein from pollen that stabilizes glasses in vitro. Biochimica et Biophysica Acta 1544, 196-206.

Wu, G., Zhang, H., Sun, J., Liu, F., Ge, X., Chen, W.H., Yu, J., Wang, W., 2011. Diverse LEA (late embryogenesis abundant) and LEA-like genes and their responses to hypersaline stress in post-diapause embryonic development of Artemia franciscana. Comparative Biochemistry and Physiology Part B: Biochemistry and Molecular Biology 160, 32-39.

Yamaguchi, R., Andreyev, A., Murphy, A.N., Perkins, G.A., Ellisman, M.H., Newmeyer, D.D., 2007. Mitochondria frozen with trehalose retain a number of biological functions and preserve outer membrane integrity. Cell Death \& Differentiation 14, 616-624.

Yancey, P.H., Clark, M.E., Hand, S.C., Bowlus, R.D., Somero, G.N., 1982. Living with water stress: evolution of osmolyte systems. Science 217, 1214-1222.

Yu, J., J. Zhang, L. Shan, S. Chen, 2005. Two New Group 3 LEA Genes of Wheat and Their Functional Analysis in Yeast. Journal of Integrative Plant Biology 47, 9. 
Table 1: Respiration rates of non-permeabilized control and transgenic Kc167 cells (D. melanogaster) expressing AfLEA1.3.

\begin{tabular}{lllllll}
\hline $\begin{array}{l}\text { Construct, } \\
\text { sucrose }\end{array}$ & $\begin{array}{l}\text { Routine } \\
\text { respiration }\end{array}$ & $\begin{array}{l}\text { Uncoupled } \\
\text { FCCP }\end{array}$ & $\begin{array}{l}\text { Leak } \\
\text { Oligomycin }\end{array}$ & $\begin{array}{l}\text { Routine/ } \\
\text { Leak }\end{array}$ & $\begin{array}{l}\mathbf{R}_{\mathbf{I}} \\
\text { Rotenone }\end{array}$ & $\begin{array}{l}\text { ROX } \\
\text { Antimycin A }\end{array}$ \\
\hline control, (-) & $15.8 \pm 0.3$ & $27.6 \pm 0.5$ & $5.5 \pm 0.1$ & $2.9 \pm 0.1$ & $2.3 \pm 0.1$ & $1.1 \pm 0.2$ \\
AfLEA1.3, (-) & $14.6 \pm 0.4$ & $20.2 \pm 1.3^{\#}$ & $4.0 \pm 0.2^{\#}$ & $3.7 \pm 0.1^{\#}$ & $1.9 \pm 0.1$ & $0.7 \pm 0.1^{\#}$ \\
control, (+) & $9.3 \pm 0.3^{*}$ & $12.7 \pm 0.5^{*}$ & $5.8 \pm 0.2$ & $1.6 \pm 0.2^{*}$ & $1.5 \pm 0.1$ & $0.6 \pm 0.1$ \\
AfLEA1.3, (+) & $9.2 \pm 0.3^{*}$ & $13.1 \pm 0.9^{*}$ & $4.9 \pm 0.2^{\#}$ & $1.9 \pm 0.1^{\# *}$ & $1.6 \pm 0.2$ & $0.7 \pm 0.1$ \\
\hline
\end{tabular}

Routine respiration of intact cells was measured in standard culture medium (-) and in standard culture medium supplemented with $0.5 \mathrm{M}$ sucrose $(+)$. All values are in $\mathrm{pmol} \mathrm{O}_{2} \cdot \mathrm{sec}^{-1} \cdot 10^{-6}$ cells $(n=4$ $8, \pm$ s.e.m.). Significance level was set as $\mathrm{p} \leq 0.05$. " Significant differences between cell lines.

*Significant differences in absence and presence of sucrose. Uncoupled respiration was induced by 5 injections of FCCP. Leak = oxygen flux after inhibition of $\mathrm{F}_{0} \mathrm{~F}_{1}-\mathrm{ATPase}, \mathrm{R}_{\mathrm{I}}=$ residual oxygen flux after inhibition of Complex I, ROX = residual oxygen flux after inhibition of Complex III. 
Table 2: Inhibition parameters calculated by fitting solute-titrations curves of permeabilized control and transgenic Kc167 cells (D. melanogaster) expressing AfLEA1.3.

\begin{tabular}{lllll}
\hline $\begin{array}{l}\text { Construct, } \\
\text { Solute }\end{array}$ & $\begin{array}{l}\text { Minimal } \\
\text { Inhibition \% }\end{array}$ & $\begin{array}{l}\text { Maximal } \\
\text { Inhibition } \\
\mathbf{\%}\end{array}$ & $\begin{array}{l}\mathbf{E C}_{\mathbf{5 0}}, \\
\mathbf{m M}\end{array}$ & $\boldsymbol{n}_{\boldsymbol{H}}$ \\
\hline control, NaCl & $1.9 \pm 3.2$ & $64.9 \pm 2.6$ & $157 \pm 9$ & $2.55 \pm 0.4$ \\
AfLEA1.3, NaCl & $1.2 \pm 3.4$ & $53.8 \pm 3.0$ & $166 \pm 12$ & $2.68 \pm 0.6$ \\
Control, KCI & $2.8 \pm 2.6$ & $64.3 \pm 4.1$ & $200 \pm 12$ & $2.00 \pm 0.3$ \\
AfLEA1.3, KCl & $0.8 \pm 3.0$ & $62.2 \pm 5.4$ & $209 \pm 17$ & $1.90 \pm 0.4$ \\
\hline
\end{tabular}

Data from Fig. 6 were fitted to the four parameter logistic inhibitor function: $f=\min +(\max -$ $\mathrm{min}) / 1+\left(\mathrm{x} / \mathrm{EC}_{50}{ }^{-n H}\right) . \mathrm{EC}_{50}$ values indicate the salt concentrations at which $50 \%$ of maximal inhibition was observed and $\mathrm{n}_{H}$ describes the Hill coefficient in the fitting routine. 


\section{FIGURE LEGENDS}

Figure 1. Deduced amino acid sequences and Kyte-Doolittle hydropathy plots of two Group 1 LEA proteins found in the brine shrimp A. franciscana (AfLEA1.1 and AfLEA1.3). (A) The proposed mitochondrial targeting sequence in AfLEA1.3 is shown in bold. (B) Kyte-Doolittle hydropathy plots of the deduced proteins AfLEA1.1 and AfLEA1.3 calculated using a moving average of 9-amino acids. Both proteins are highly hydrophilic and score well below zero with the exception of a 17 amino-acid region located close to the N-terminus of AfLEA1.3 but lacking in AfLEA1.1. The deduced mitochondrial targeting sequence (predicted by MitoProt II) is highlighted in red.

Figure 2. Subcellular locations of LEA 1 proteins expressed in D. melanogaster cells (Kc167). Proteins were labeled by fusion to green fluorescent protein (GFP). Chimeric proteins composed of AfLEA 1.1 (panel A, frames a-c), or AfLEA1.3 (panel B, frames a-c) are shown and costaining with Mito Tracker red highlights the mitochondrial network (Ab, $\mathrm{Bb})$. Green and red fluorescence are colocalizing in cells expressing AfLEA1.3-GFP (Bc) but not in cells expressing AfLEA1.1-GFP (Ac).

Figure 3. Western blot identification of AfLEA1.3 protein transgenically expressed in $D$. melanogaster cells (Kc167). Lane a, molecular weight standards; lane b, extract of control cells probed with antibody against the V5 epitope; lane c, extract of cells stably transfected with AfLEA1.3 and probed with antibody against the V5 epitope.

Figure 4. Respiration of permeabilized D. melanogaster cells (Kc167) in mitochondrial medium. (A) Traces of oxygen concentration (dashed) and oxygen flux (solid) for cells expressing AfLEA1.3. Oxygen flux is shown after addition of cells (Routine) plus digitonin (Dig), malate (M), glutamate (G), pyruvate (P), succinate (S), ADP (D), cytochrome c (Cyt-c), oligomycin (Omy), FCCP, rotenone (R), and antimycin A (AMA). (B) Oxygen consumption of permeabilized Kc167 cells (black bars) and Kc167-AfLEA1.3 cells (grey bars) in presence of substrates and inhibitors $(n=6-7, \pm$ s.e.m.). Significance level was set at $\mathrm{p} \leq 0.05$. *Significant differences between both cell lines. OXPHOS = oxygen flux in presence of substrates and ADP, 
LEAK $_{0}=$ oxygen flux after inhibition of $\mathrm{F}_{0} \mathrm{~F}_{1}$-ATPase, ROX $=$ residual oxygen flux after inhibition of Complex III.

Figure 5. Percent inhibition of respiration in permeabilized D. melanogaster Kc167 (square, solid line) and Kc167-AfLEA1.3 (triangle, dashed line) cells measured at increasing concentrations of $\mathrm{NaCl}$ (black) or $\mathrm{KCl}$ (gray, dashed line). Oxygen flux was measured in presence of malate, glutamate, pyruvate, succinate, ADP, and percent inhibition calculated at each of 10 successive titration steps raising salt concentrations by $50 \mathrm{mM}$ each $(n=4$, \pm s.e.m.). For additional information see text. Significance level was set at $\mathrm{p} \leq 0.05$. *Significant differences between cell lines.

Figure 6. Effect of freezing on respiration rates of mitochondria isolated from Kc167 and Kc167-AfLEA1.3 cells. Oxygen flux is shown after addition of mitochondria and malate, proline, pyruvate (MProP), ADP (D), succinate (S), sn-glycerol-3-phosphate (G3P), cytochrome $c$ (Cyt-c), rotenone (R), oligomycin (Omy), and antimycin A (AMA) $(n=4-6, \pm$ s.e.m.). Significance level was set at $\mathrm{p} \leq 0.05$. "Significance differences before and after freezing of mitochondria. *Significant differences between mitochondria isolated from Kc167 and Kc167AfLEA1.3 cells.

Figure 7. Effects of hyperosmotic stress on proliferation rates of control Kc167 cells and cells expressing AfLEA1.3 (D. melanogaster). Kc167 (black) and Kc167-AfLEA1.3 (gray) cells were cultured at several sugar concentrations for $48 \mathrm{~h}$ in fully supplemented medium. The number of viable cells observed at each sucrose concentrations is expressed as percentage of viable cells found under control conditions ( $0 \mathrm{mM}$ sucrose $)(n=9$, \pm s.e.m.). For additional information see text. Significance level was set at $\mathrm{p} \leq 0.05$. * Significant differences between cell lines.

Figure 8. Viability of D. melanogaster (Kc167) cells after drying and rehydration. Kc167 control (black) and AfLEA1.3 expressing (gray) cells were convectively dried in droplets of 15 $\mu 1$ medium containing $200 \mathrm{mM}$ trehalose. Cells were dried to a range of final moisture contents, rehydrated, and cultured for $24 \mathrm{~h}$ in fully supplemented medium without trehalose. The number 
of viable cells observed at a given moisture content $\left(\mathrm{gH}_{2} \mathrm{O} / \mathrm{gDW}\right)$ is expressed as percentage of viable cells found on non-desiccated control plates. Expression of AfLEA1.3 significantly changed the cellular response to desiccation (ANCOVA: F1, 132 $=49.69, \mathrm{P}<0.0001, \mathrm{r}^{2}=0.74$ ). 


\section{Figure 1}

\section{A}

AfLEA 1.3 MELSSSKLNRSIFKRSSSVLHWHFYRLFGKKYPSKMSEQGKLSRQEAGQRGGQARAEQLG AfLEA1. 1 MELSSSKLNRSIFKRRS---------------KMSEQGKLSRQEAGQRGGQARAEQLG $\star * * * * * * * * * * * * * * *$

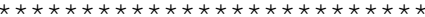

AfLEA1.3 HEGYVEMGRKGGQARAEQLGHEGYQEMGQKGGEARAEQLGTEGYQEMGQKGGQKRAEQLG AfLEA1.1 HEGYVEMGRKGGQARAEQLGHEGYQEMGQKGGQARAEQLGTEGYQEMGQKGGQKRAEQLG

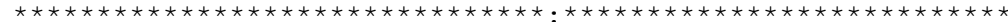

AfLEA1.3 HEGYQEMGQKGGQTRAEQLGTEGYQEMGQKGGQTRAEQLGHEGYVQMGKMGGEARKQQMS AfLEA1.1 HEGYQEIGQKGGQTRAEQLGTEGYQEMGQKGGQTRAEQLGHEGYVQMGKMGGEARKQQMS

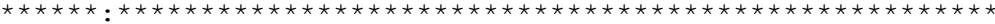

AfLEA1.3 PEDYAAMGQKGGLARQK AfLEA1.1 PEDYAAMGQKGGLARQK

\section{B}

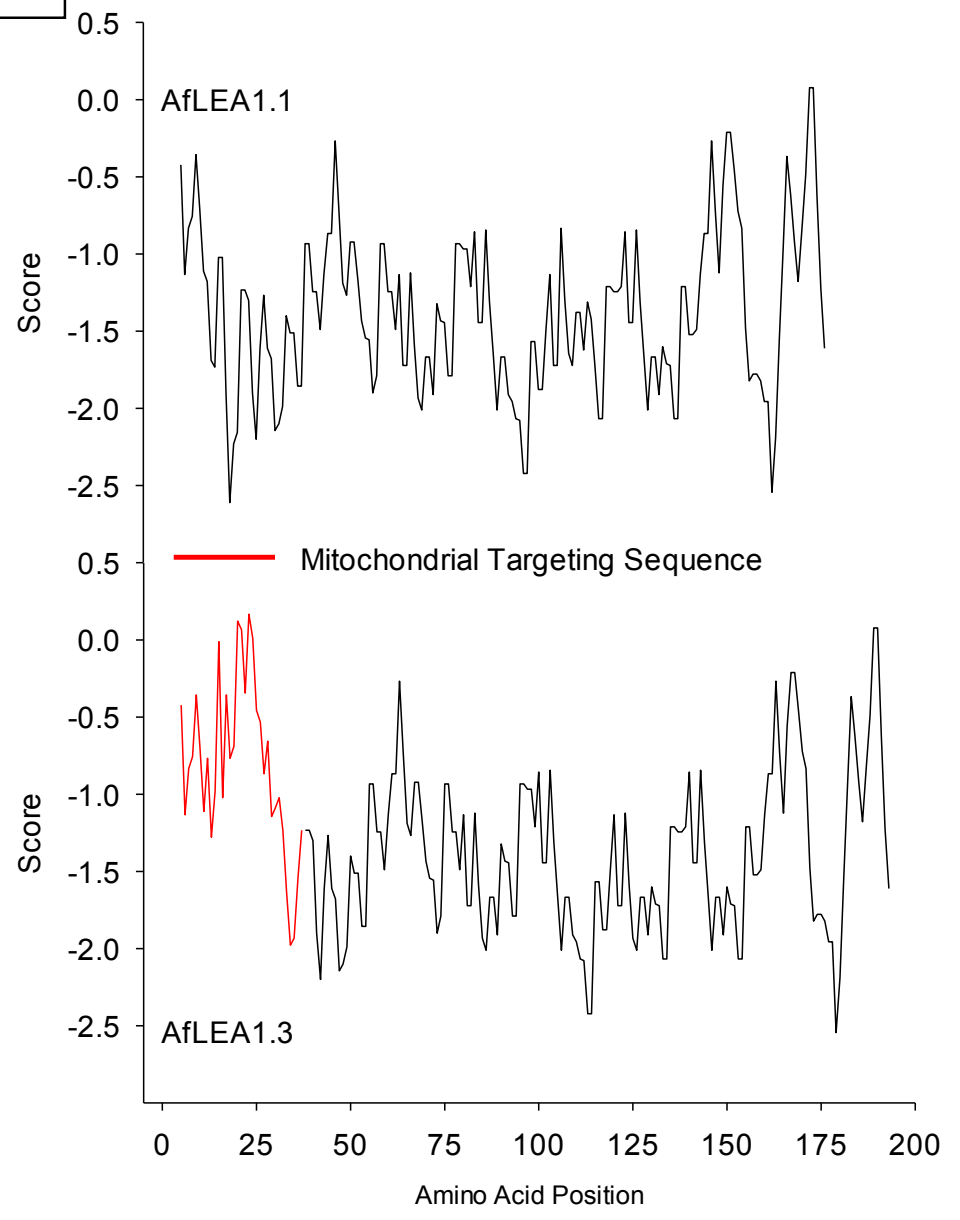


Figure 2
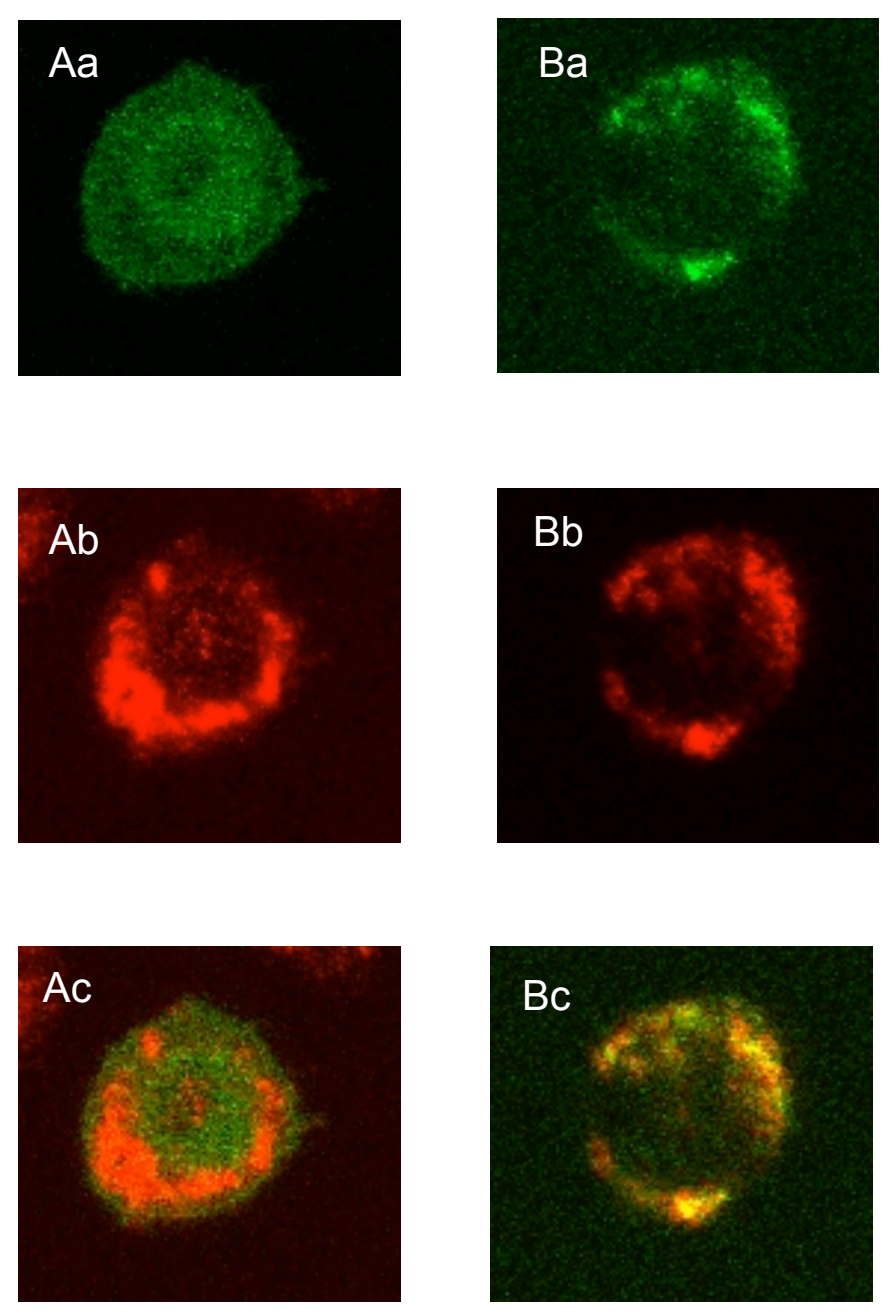
Figure 3

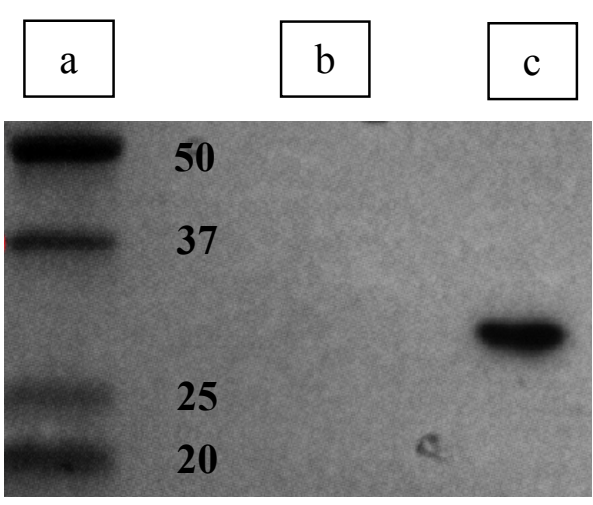


Figure 4
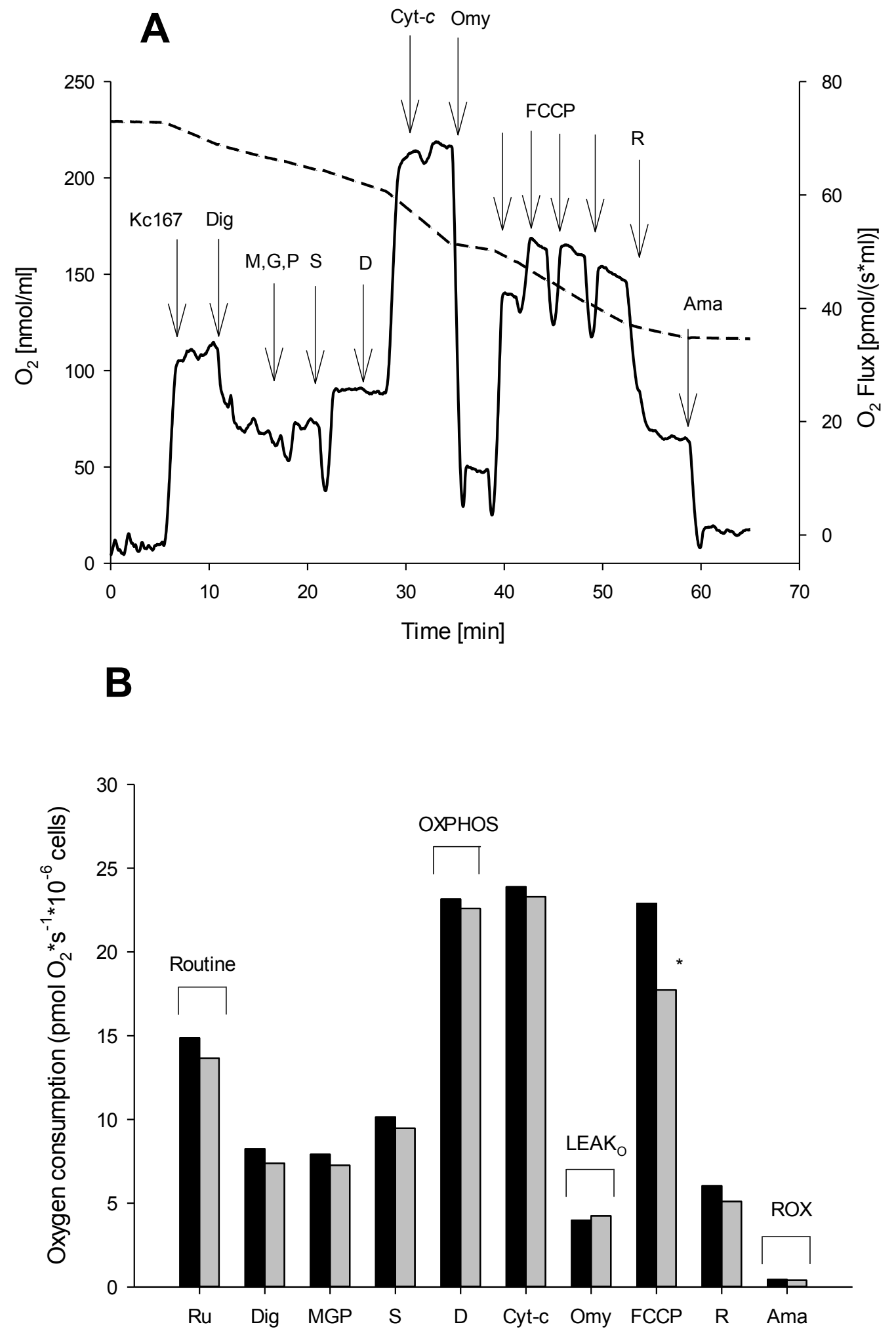
Figure 5

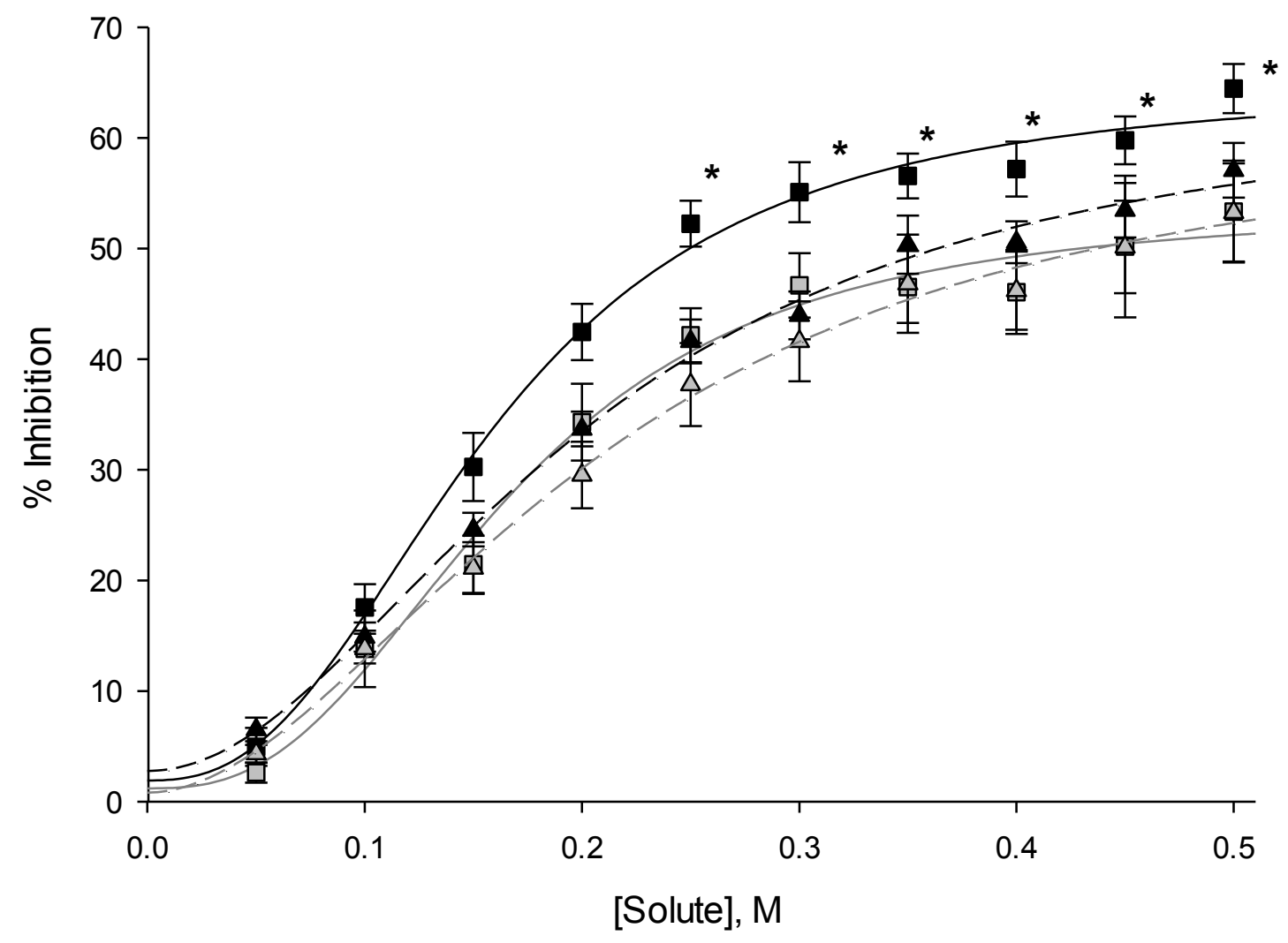


Figure 6

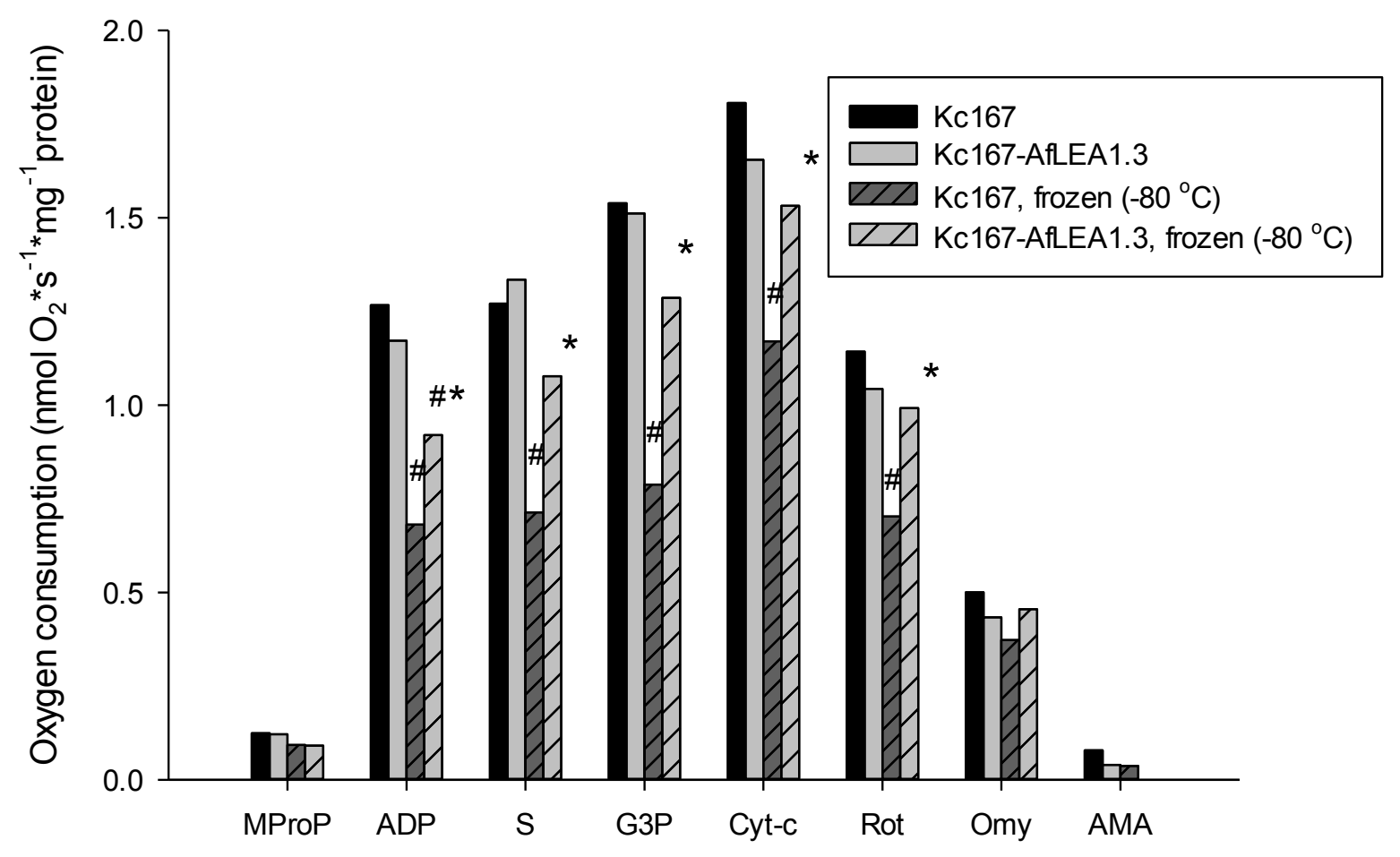


Figure 7

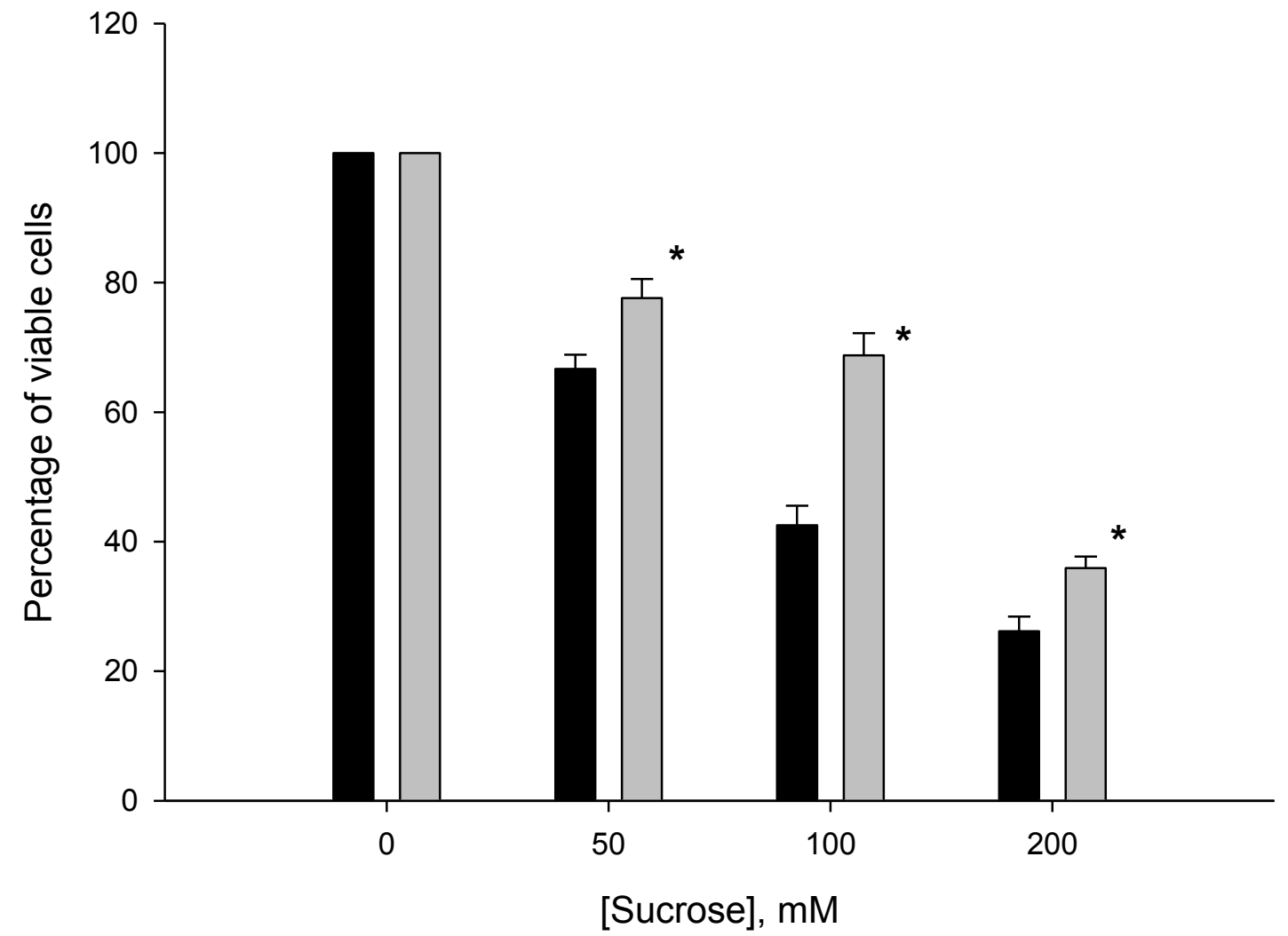


Figure 8

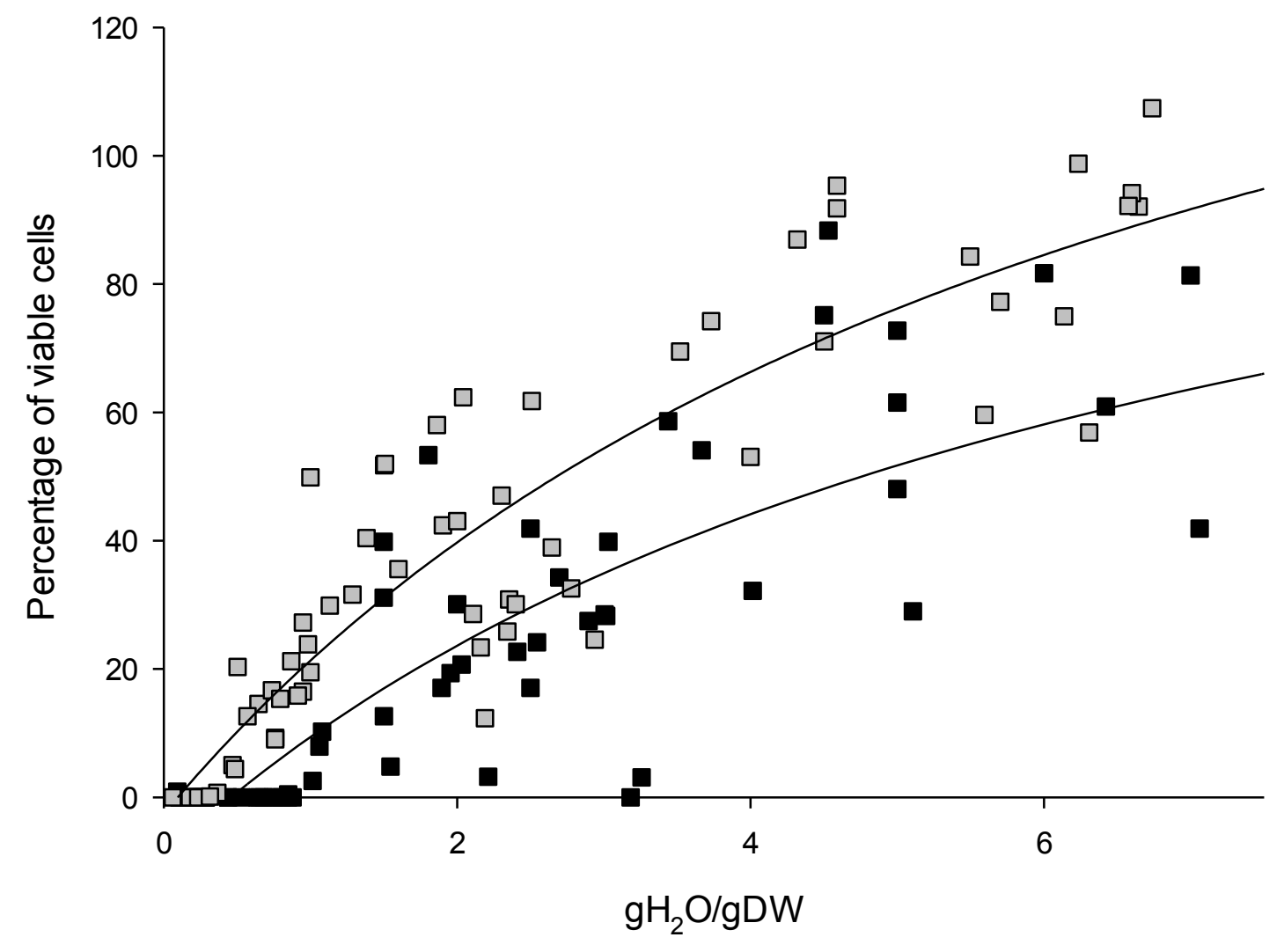

